\title{
A STUDY OF A MARINE BENTHIC COMMUNITY WITH SPECIAL REFERENCE TO THE MICRO-ORGANISMS
}

\author{
By Molly F. Mare \\ Research Fellow of Newnham College, Cambridge
}

(Text-figs. I-3)

CONTENTS

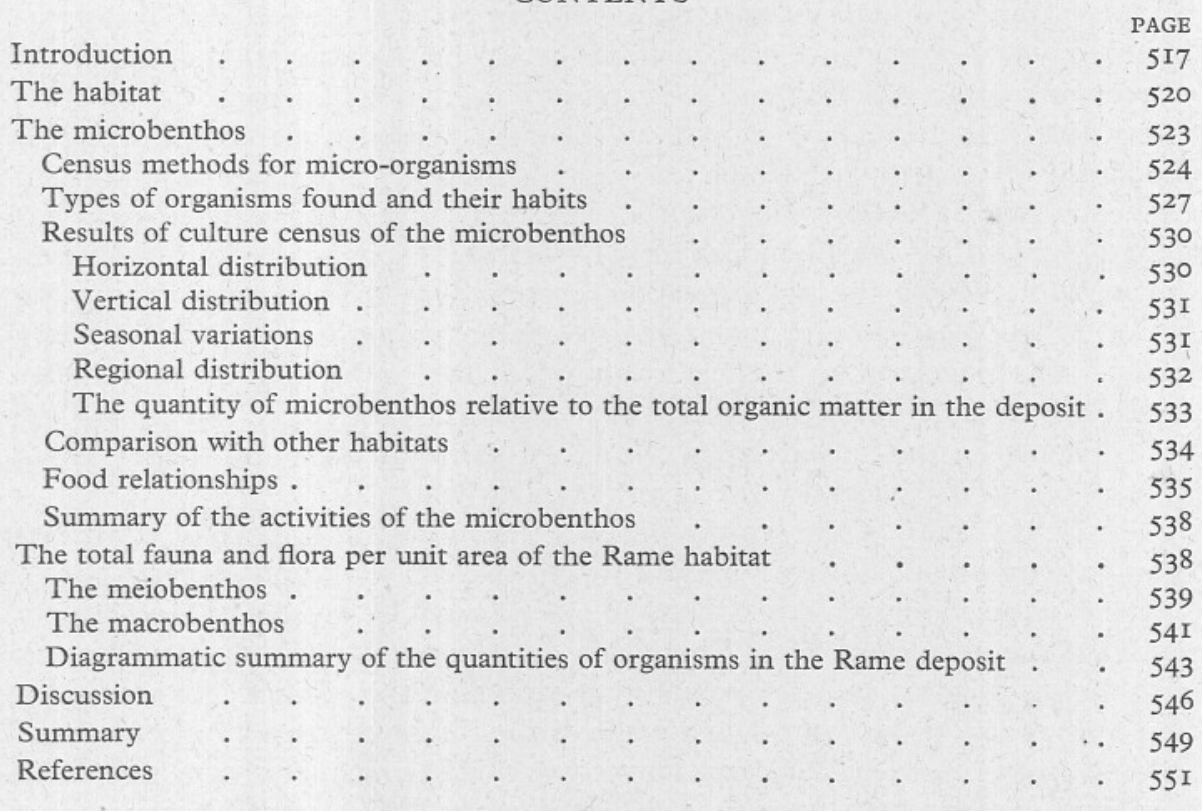

\section{INTRODUCTION}

The object of these investigations is to make some contribution to the understanding of that part of the marine food cycle which takes place on the sea bottom. A marine mud sediment, off Rame Head near Plymouth, under relatively open sea conditions was chosen for this study. A preliminary account ${ }^{1}$ is first given of the quantities and types of micro-organisms found in the surface layers of the deposit. In such a place organic matter is continually settling, and under aerobic conditions a rich and varied population of micro-organisms is present. An attempt has been made to treat these ${ }^{1}$ Owing to the war further samples could not be obtained. 
micro-organisms as a community. Special attention was paid to the surface layer because it is an important feeding zone for detritus-eating members of the macrofauna, and a subsidiary problem was the question of the relative importance of detritus and micro-organisms as the actual food supply of the macrofauna. Under the term detritus is included all material of living origin at any stage of disintegration and decomposition, from recently dead plant or animal or part thereof to the finest particle. The final stages of some of the products of decomposition, being colloidal or true solutions, are not included under the term; they are likely to be of food value to bacteria and minute saprophytes.

A brief census was also made of most of the larger fauna. A census of organisms over the whole range of individual size is a necessary preliminary to the understanding of quantitative food relationships throughout the community of micro-organisms and larger animals. It is also necessary for assessing the relative importance of the various groups in the utilization of deposited phytoplankton and detritus and the extent to which loss of organic matter from circulation is prevented. Fig. I shows the main phases of the complex marine food cycle. The parts with which this paper is specially concerned are indicated by heavy type. The part which takes place in the overlying water masses has been described for the Plymouth area by Harvey, Cooper, Lebour \& Russell (1935), and data on the phytoplankton crop and its consumption during the period when these bottom investigations were in progress is given in Mare (1940). The turn-over in the water (shown at the top of Fig. I) is probably rapid and considerable (Gardiner, I937, Harvey, 1940, 1942), but in shallow water events on the bottom merit some consideration although their relative importance in the general cycle is as yet unknown.

The productivity of the sea bottom was the subject of important contributions by Petersen and Boysen Jensen (I9I I, I9I4, I9I8, I9I9) and Blegvad (I9I4). These workers were concerned with the macrofauna, its sources of food supply and its utilization as fish food. There have since been numerous papers dealing with the macrofauna and some with other aspects of the subject. An investigation of the food of the macrofauna made in the Plymouth area by Hunt (I925) showed clearly the need for quantitative work on the smaller organisms of the benthic fauna and flora. Several workers have studied copepods, nematodes, foraminifera, etc., in submarine deposits and also the bacteria; but except for qualitative work on the protozoa by Remane (I933) and Lackey (I936) no ecological study has previously been made of the protozoa and algae of the marine benthos.

On the bottom is a fauna of detritus eaters and predators which may be separated for convenience according to size or weight into three groups. Associated with these differences is another factor, the generation time, which, though by no means easy to determine, varies enormously between the groups and is important in considering the role of the various organisms in the community. A new terminology is needed, and these groups are here designated 
the macrobenthos, meiobenthos ${ }^{1}$ and microbenthos. The macrobenthos is equivalent to the macrofauna of the bottom, and would also include large attached

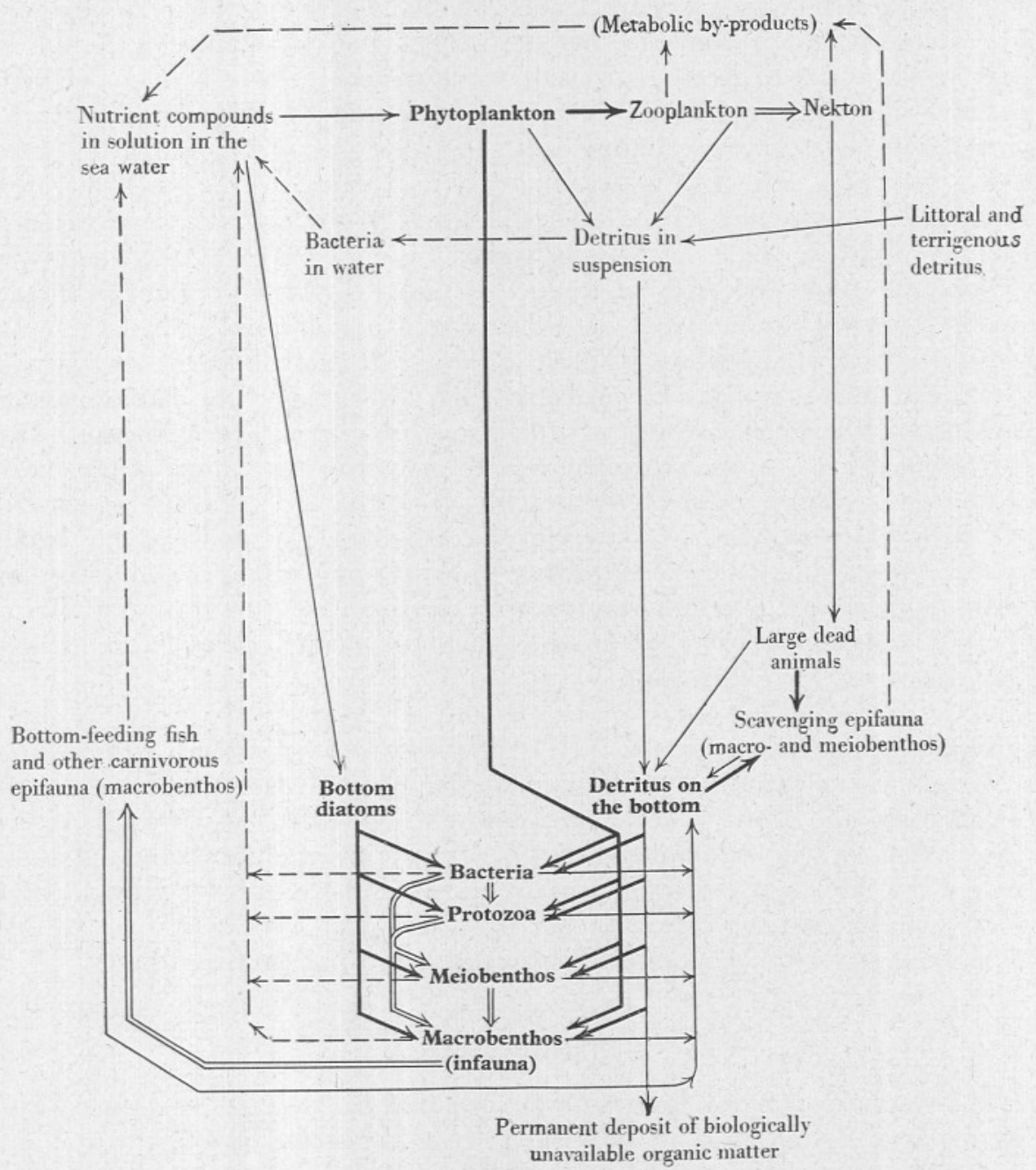

Fig. I. Diagram of the main phases of the marine food cycle. Above are stages which take place in the water and below are those which take place on the bottom surface and in the deposit. Heavy type indicates the material with which this paper is concerned. Plant and detritus consumption, $\longrightarrow$; predatory relationships $\Longrightarrow$; metabolic changes, $-\longrightarrow \rightarrow$; other changes, $\longrightarrow$.

algae in habitats where they occur. The meiobenthos here comprises the fauna of intermediate size, such as small crustacea (copepods, cumaceans, etc.) small polychaetes and lamellibranchs, nematodes and foraminifera. The

\footnotetext{
1 Greek meion, smaller.
} 
microbenthos comprises all the small organisms-protozoa (excluding foraminifera, i.e. ciliates, amoebae and flagellates), bottom diatoms and bacteria. The word micro-organisms here denotes all the members of the microbenthos. The fauna of intermediate size has been called the microfauna by Krogh \& Spärck (1936) and by Rees (1940), and Remane used the term to include small metazoa and some protozoa. In a freshwater deposit Rawson (1930) employed a similar usage, including small metazoa and such protozoa as were found by direct searching under the term microfauna; some small metazoa appeared also in the lists of the macrofauna and he did not consider algae and bacteria. This use of the term seems rather unsatisfactory and inadequate for the present study. Bacteria are frequently called the micro-organisms of the sea bottom, but the omission of protozoa and diatoms has been largely on account of lack of knowledge of these groups. The exact limits of the macro-, meio- and microbenthos will probably vary according to the habitat under consideration and the methods which have to be employed for collection. The two larger groups can be separated according to size, depending on the mesh of the sieves employed for their extraction from the deposit. The groups can also be separated on the basis of weight, the weights of the microbenthos being deduced from volumes. The difference in generation time provides a further reason for separating the foraminifera with the small metazoa from the microbenthos. For a more exact definition of the limits of the groups in the habitat here described see Table VIII, p. 545.

This work was carried out at the Plymouth Laboratory while I was holding a Newnham College Research Studentship and a grant from the Department of Scientific and Industrial Research. I wish to thank the Director of the Laboratory for the numerous facilities given me, and to thank the staff, particularly $\mathrm{Mr} \mathrm{G}$. A. Steven, and visiting research workers for many helpful discussions during the course of the work, and also Prof. J. Gray, Dr M. Rosenberg and Dr J. E. Smith for helpful criticism of the typescript.

\section{The Habitat}

The station at which regular samples were taken is about one mile westsouth-west of Rame Head, to the west of Plymouth Sound, at a depth of about $45 \mathrm{~m}$. The conditions are those of a relatively shallow open coast, where the bottom is sometimes considerably disturbed by storms. The habitat thus differs from any previously described in detail by workers on the meio- and microbenthos, such as bottom stations in the Clyde worked by Moore (I93I) and Lloyd (1931) and from the sheltered Danish waters.

Samples were collected by means of a weighted metal tube into which fitted a glass lining tube, with a plate valve at the upper end. This core sampling apparatus was a modification of that designed by Moore \& Neill (1930). It brought up cores $5-15 \mathrm{~cm}$. long with the surface layers practically undisturbed. 
The deposit at the Rame station was a sandy mud, fawn to grey in colour. The amount of coarse material $(5-0.5 \mathrm{~mm}$. in diameter) was very variable in different samples, but the fraction of greatest weight was always made up of particles $0.25-0.1 \mathrm{~mm}$. in diameter, and very fine silt (from $40 \mu$ to less than I $\mu$ in diameter) contributed about $25 \%$ of the dry weight and was, of course, important in determining the texture. There was no clear demarcation into zones within the depth sampled.

All water was rapidly expelled by heating at $I \mathrm{IO}^{\circ} \mathrm{C}$. The surface layers were more fluid than the rest, which retained its form when removed from the tube. In the surface $\frac{1}{2} \mathrm{~cm}$. layer the water content was about $57 \%$ of the wet weight and $30-33 \%$ at a depth of $5 \mathrm{~cm}$. It was noticed that in a set of samples collected after rough weather the loose texture of the surface mud extended appreciably farther down the cores. The volume of interstitial space was found to be approximately the same as that occupied by the particles. The fine silt lying between the larger particles could easily be brushed aside by motile members of the microbenthos, for which the microscopic topography is an important factor. Active holotrichous ciliates about $28 \times 10 \mu$ in size were common, and hypotrichous forms, up to $50 \mu$ long, have been seen. Nematodes and polychaetes would burrow between the larger particles and ingest some of the finer ones. Harpactacid copepods seemed to be restricted almost entirely to the less compact surface layer. This restriction was probably also correlated with oxygen supply.

The total organic carbon content was about $\mathrm{I} \%$ of the dry weight of the deposit, as determined by a wet dichromate oxidation method, slightly modified from Anderson (I939). Coal was frequently detected in samples of the deposit from this and other stations near the port of Plymouth, but fortunately it was scarcely oxidized by the method here used. The presence of coal as a contaminant in bottom samples has received little mention previously (see Trask, 1932). By no means all the organic detritus on the sea bottom is of equal use to the fauna or to the bacteria. Waksman \& Hotchkiss (I938) and Anderson (1939) have found that the biologically utilizable fraction, as indicated by the oxygen consumption of micro-organisms oxidizing it and feeding on it in culture, represents only a small part (about one-sixth to one-tenth) of the organic matter found by the dichromate method.

Only on prolonged standing in the laboratory did the cores develop irregular black patches due to the presence of sulphide; it was therefore thought probable that the habitat normally contained some free oxygen in the surface layers.

Microscopic investigation of the deposit gave a further picture of the environment of the micro-organisms. Mud was frequently compacted into faecal pellets by the activities of the small polychaetes and lamellibranchs. No deposition of recognizable green faecal pellets of planktonic copepods, such as was found by Moore (I93I) in the Clyde, was detected, although such pellets were common in the water. Large particles in the deposit consisted of siliceous 
and calcareous skeletal fragments often with pores or cavities. While these still contained organic remains they would probably cause aggregations of bacteria and protozoa therein (thus similar difficulties in dispersing the micro-organisms prior to counting arose with this material as with land soil). The following list was typical of the objects encountered, and it gives an indication of the sources of supply to the region.

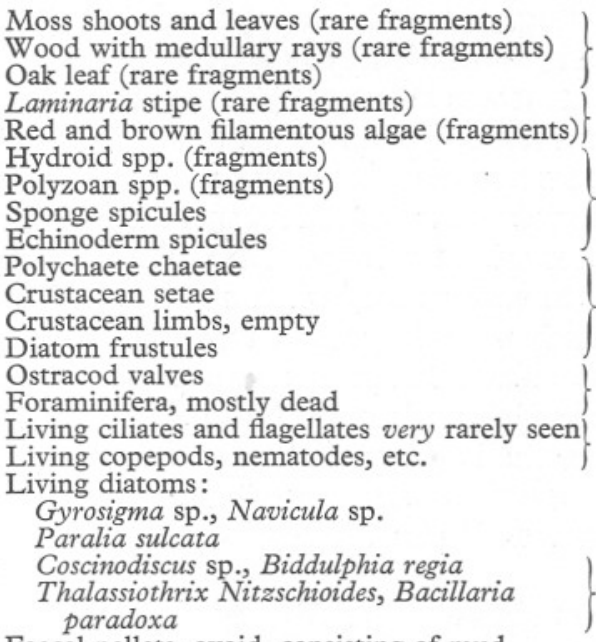

alk leaf (rare fragments)

Red and brown filamentous algae (fragments)

Hydroid spp. (fragments)

Sponge spicules

Echinoderm spicules

Cruchaete chaetae

Crustacean limbs, empty

Diatom frustules

stly dead

Living copepods, nematodes, etc.

Navicula sp.

Coscinodiscus $\mathrm{sp}$., Biddulphia regia paradoxa
cal pellets, ovoid, consisting of mud

\author{
Origin \\ Terrigenous \\ Littoral benthic \\ Benthic (including intertidal) \\ Planktonic or benthic (some indigenous) \\ Benthic (some indigenous) \\ Indigenous fauna \\ Indigenous benthic or tychopelagic \\ Tychopelagic \\ Planktonic
}

Products of the smaller macrobenthos

Note. The littoral zone is here used to include the intertidal region and down to the limits of attached vegetation. The Rame station is regarded as being in the sublittoral zone, in which it now seems very probable that pennate diatoms are present and active (see pp. 528 and 535 ). The term tychopelagic is applied to organisms which are associated with the bottom and may be washed up into the plankton. Diatom nomenclature is that used by Lebour (I930).

The nature and quantity of the organic fragments occurring on the bottom is dependent on the depth, the distance from land and on the local conditions of settlement. A few samples taken with the Hunt vacuum grab (Hunt, I926) from coarse deposits farther seawards and taken from intertidal stations at Wembury and Laira illustrated the influence of these factors and also showed an interesting distribution of planktonic and bottom diatoms (see p. 533). The occurrence of the latter was associated with differences in light intensity. Hunt (1925) deduced that phytoplankton was in all probability the chief ultimate source of supply of organic matter to the bottom in the Plymouth region.

It should be noted from the above list that protozoa, bacteria and small diatoms were hardly ever encountered in direct searching, even though alive and active and found by other means to be very numerous. Petersen and Boysen Jensen (I9II) stated as a result of direct microscopic examination that "Of living organisms apart from bacteria and higher animals there are but few; one or two living bottom diatoms were met with." Krogh and Spärck 
(I936) gave values for the numbers of "infusoria" found by direct searching, which from the results obtained by another method at Rame would appear to be far too small, but perhaps they refer only to very large ciliates. Investigators of the soil protozoan population have found direct searching to be valueless, as protozoa have a definite affinity for the soil particles, adhering closely to them so that they are hardly ever seen. The relatively enormous number of silt particles compared with the living organisms would also tend to make such a method very unsatisfactory for assessing the numbers present. The number would change appreciably before many samples could be counted.

\section{The Microbenthos}

A study has been started of the types, numbers and distribution of the microorganisms and the quantity of living matter present in the surface layers of the mud deposit at the Rame station. A little information about the part played by these micro-organisms in the food cycle is here collected: it has been shown that indigenous photosynthetic organisms are present on the sea bottom; the importance of bacteria as converters of organic debris is known chiefly from the work of Waksman et al. and ZoBell et al.; data are here given on the feeding habits of some of the protozoa of the Rame microbenthos. The ways in which bacterial and protozoan populations interact, and particularly the influence of protozoa on bacterial activities associated with the regeneration of nutrient salts, are important subjects which have yet to be explored in marine habitats.

There has as yet been little ecological work on populations of microorganisms treating them as communities rather than as collections of individuals. The most extensive work of the type indicated above has been carried out by Cutler, Crump \& Sandon and others at Rothamsted on soil populations. Special attention was there paid to the determination of the numbers of organisms present, to fluctuations in abundance, and the influence of protozoa on bacterial activities affecting soil fertility. Picken (I937) described the structure of some freshwater protozoan communities, laying stress on the interrelationships of the organisms with each other on the basis of food chains, and their dependence on the structure of the habitat. In a distributional study of the microscopic benthic fauna of a Michigan lake, Moore (I939) noted the effects of depth, type of deposit and of seasonal changes in the oxygen concentration on the numbers and species of such protozoa as were observed by direct search.

In marine habitats, the nannoplankton was investigated extensively by Lohmann (I908, I9II), who determined the numbers and volumes of all the minute organisms of sizes comparable with the microbenthos, and placed them in relationship with the rest of the plankton. The predatory activities of protozoa in the water are held by Waksman \& Hotchkiss (I937) and others to be important in limiting the numbers of bacteria normally found in sus- 
pension in the sea. Lackey (1936) made qualitative studies of the protozoa from the water and from the bottom and discussed their possible roles, pointing out that protozoa have an important function in the turn-over of organic matter. For example, a dead copepod is soon invaded by bacteria, followed by ciliates, which, after escape from the carapace, may serve as food particles of convenient size for metazoan filter feeders. 'The holozoic and saprophytic forms attack organic debris in suspension and constantly convert it to protoplasm in part and accomplish its mineralization in part. If they do not compare with the bacteria in numbers, their size is a compensation for this.' $\mathrm{He}$ also suggested that the smaller and presumably saprozoic flagellates may act as 'food condensers' for the larger forms.

The only members of the microbenthos which have so far been investigated in detail are the bacteria. Lloyd (I93I), Waksman et al. (I933 et seq.) and ZoBell et al. (1936 et seq.) have investigated bacterial numbers, distribution and physiological types in sea water and in bottom deposits. They have been concerned with the bacteria and with the net effects in nutrient salt regeneration and have not investigated the influence of protozoa in the benthic community.

The possibility that marine fungi might be present on the bottom was investigated by Sparrow (1937), who found no typically marine forms there, and stated that it was doubtful if fungi are present in a trophic state or take any part in the decomposition of organic detritus.

An attempt is here made to fill in one of the gaps in our knowledge of the organisms of the sea bottom, and investigations have been made in detail on the protozoa and algae present on the bottom. Some work on bacteria has been included.

\section{Census Methods for Micro-organisms}

\section{Routine Procedure}

The routine procedure for obtaining a sample and for its subdivision was as follows. The core sampling apparatus used has been described on p. 520 . A sterile glass tube was fitted for taking each sample and at least ten good cores were obtained. Since the surface area of each core was $2.54 \mathrm{~cm} .{ }^{2}$, census data of the micro- and meiobenthos (expressed as numbers per gram of dry deposit or numbers per unit area) are from mud derived from an area of $25.4 \mathrm{~cm} .{ }^{2}$, unless otherwise stated. Full precautions were taken against contamination by extraneous organisms in the laboratory and on board ship. A flow of water through the tube during its descent was, however, inevitable; but despite this, calculations showed that there could have been no significant contamination by organisms from the water. No contamination was possible during ascent, with the glass tube plugged at the bottom by the core of mud (the bottom of which was discarded) and closed at the top by the valve. Immediately on being brought on deck, sterile corks were put in both ends of the tube. The cores 
were transported vertically in an ice box and used immediately on arrival in the laboratory (2-3 hr. after being taken). The supernatant water was siphoned off each in turn to just above the surface of the mud, and the level of $\frac{1}{2} \mathrm{~cm}$. down the core was marked with a rubber band. Sterile water was then added and the top $\frac{1}{2} \mathrm{~cm}$. of mud with this water siphoned over into a sterile burette, where the volume was measured before discharge into a flask. The open ends of the sample tube and the flask were protected by sheet rubber hoods. In this way none of the rather fluid surface layer was lost and contamination in the whole process was found experimentally to be quite negligible. Any organisms migrating up or thrown into suspension just above the surface of the mud were included with those living in the surface layer. The suspension was used first for setting up the bacterial count and then for the protozoan and algal census. An aliquot sample of 50 c.c. was also taken to ascertain the dry weight of the mud. The total volume of mud and water from ten cores was usually about 350 c.c., containing about $\frac{1}{25} \mathrm{~g}$. of mud per cubic centimetre of suspension.

\section{Census Method for Bacteria}

Work on bacteria was restricted to assessing the number of aerobes present (without further distinction of types), and to evaluating the bacterial contribution to the total bulk of living matter. Bacteria were plated from dilutions of approximately I/2500 and I/25,000. After a comparison of several media, including those used by Waksman et al. (1933) and ZoBell \& Anderson (1936), it was found that the medium giving the highest counts was that used by Waksman with the interesting addition of a trace of iron:

$\begin{array}{lrlr}\text { Sea water } & \text { I000 c.c. } & \mathrm{K}_{2} \mathrm{HPO}_{4} & 0.05 \mathrm{~g} . \\ \text { Bactopeptone } & \text { I g. } & \mathrm{FeCl}_{3} \text { (anhyd.) } & 0.0125 \mathrm{~g} . \\ \text { Glucose } & \text { I g. } & \text { Agar } & \text { I5 g. }\end{array}$

The optimum $p \mathrm{H}$ was found to be 7.5 (as shown by cresol red corrected for salt error). The suspension was shaken for $3 \mathrm{~min}$. immediately before plating to disperse aggregations of bacteria. Incubation was at room temperature and the plates were observed after I4 days, by which time significant differences were easily detected. There are so many factors slightly affecting the numbers of bacterial colonies counted that it was considered safe only to compare plates set up on the same day.

The plate count represents only a small and not necessarily a constant fraction of the total number of bacteria present in the habitat, owing to the impossibility of finding a medium or conditions in which all types of bacteria will develop. Direct count methods were tried but found inapplicable to a marine sediment. Data obtained by workers on other habitats (soil, fresh water and sea water) show that their plate counts represent something of the order of one-hundredth of the numbers they obtained by direct counts. The latter, however, include dead as well as living bacteria. 


\section{Census Method for Protozoa and Algae}

A dilution culture method, modified from that used by soil microbiologists (see Cutler, 1920; Cutler et al. I922), was used to count the protozoa and algae. The suspension of mud was diluted by stages and I c.c. samples plated out into Petri dishes containing a suitable medium. The dilution stages were in orders of two or four with, respectively, one or two plates at each dilution. A range of dilutions from approximately I/25 to I/I02,400 was necessary to include all the protozoa and to $I / 6,553,600$ to cover all the diatoms. The medium which was found to encourage the greatest variety of species was made up as follows:

$\begin{array}{lrlr}\text { Sea water } & \text { rooo c.c. } & \text { Cystine or methyonine } & \text { ro mg. } \\ \mathrm{NaNO}_{3} & \text { O.I g. } & \text { Gluconic acid } & 2 \mathrm{mg} \text {. } \\ \mathrm{Na}_{2} \mathrm{HPO}_{4} & 0.02 \mathrm{gg} . & \mathrm{Fe} \cdot * & 0.1 \mathrm{mg} \text {. } \\ \text { Sea mud extract } & \text { I00 c.c. } & \mathrm{Mn} * & 0.02 \mathrm{mg} .\end{array}$

The nitrate and phosphate are necessary for plant growth. The sea-mud extract was made by autoclaving mud from the Rame habitat, in a similar way to the soil extract used by Gross (1937). The last four ingredients had recently been found advantageous to the growth of diatoms by Harvey (1939). This medium was found to give a much greater variety of species than media richer in organic matter, in which bacterial growth was liable to be excessive. By keeping the cultures in a dull light at $\mathrm{I}^{\circ} \mathrm{C}$., a satisfactory gradual succession of species was obtained. The plates were examined at weekly intervals, samples being removed with a fine sterile pipette for recognition of species.

From the presence or absence of any particular species down the dilution series the number of positive plates for that species is recorded, and from this the original concentration of the species can be calculated (see Cutler et al. I922, table iii, p. 34I). It is assumed (and there is definite evidence in some cases) that any single organism is capable of giving rise to a population which on examination of the dishes will be detected. However, with a wide variety of species in mixed culture (see p. 528) each of the individuals of a species in a dish sometimes inevitably fails to multiply. Some allowance can be made for such gaps from a table ${ }^{1}$ of the probabilities of occurrence of the various types of end-point in the dilution series. For estimates of the total population, the filling in of obvious culture gaps is essential. These estimates are in any case minimal values for the population, and with standardized conditions and technique, valid comparisons can be made between parallel series from different places and between successive samples from the same place. The significance or otherwise of the differences obtained is tested on the number of positive plates, reliance being placed on those species which show few or no culture gaps. A difference of at least three plates is significant for any single species, and therefore where such a difference occurred, the numbers of that species per gram of deposit were also significantly different. Since groups of species compared showed the same tendency for high or low figures these smaller grouped differences were usually significant. The method was tested as

${ }^{1}$ A table kindly prepared for my use by $\mathrm{Mr}$ G. M. Spooner. 
follows: it was used to count a ciliate population of known density, and in each of two tests with three parallel dilution series the number of positive plates was within one plate of the expected number. In making two parallel estimations of the same natural mixed population, technical variations were found to be insignificant.

In the tables on pp. 530-533, the numbers are given per gram of dry mud. The volume of an organism has been calculated from its dimensions, using individuals of average size found in culture. The volumes of all species have been summed to give the volume of protoplasm (in cubic millimetres) contributed by a group such as ciliates or amoebae to the total bulk of living matter forming the microbenthos.

\section{Limitations of Methods}

A clear distinction must be drawn between the value of these census methods for comparative purposes and for giving absolute numbers. Although they cannot be made very accurate, with standardized technique they are adequate for comparative work when large differences are involved. The absolute number of living bacteria lies between the number deduced from the plate count and approximately roo times that number. The census method used for the other micro-organisms includes both the trophic forms and any resting stages there may happen to be on the bottom, but it is a minimal value for the total number of organisms because an unknown number of species may have failed to develop under the conditions provided. At present there is no more adequate method available.

A comparison of direct and culture counts, made on a sand deposit, illustrated the difficulties and limitations of both census methods. For protozoa and small diatoms the culture method gave much higher figures; but only a few of the larger planktonic diatoms seen in direct search had responded to culture conditions because some of the vegetative cells were too moribund to reproduce; others may have found the conditions or the media unsuitable. There was, however, some development of resting spores. By culturing a sample of detritus freshly deposited from sea water into a glass dish, in which only a few species were found by direct observation, Lackey (1936) obtained several other species of protozoa and algae by excystment. One must therefore be very cautious in discussing results obtained only' by culture methods, but for members of the microbenthos, direct examination has led to erroneous results (see p. 522).

\section{Bacteria}

\section{Types of Organisms found and their Habits}

Rods and cocci were common, including motile forms. Measurements indicated that the average volume was about $\mathrm{I} \mathrm{cu} . \mu$. This figure was used by ZoBell \& Feltham (1938) and Baier (1935) for calculations of an available food supply. The physiological types have been investigated by 
several workers, recently by Waksman et al., ZoBell et al. and Lloyd. ZoBell (1939) reviewed the subject of bacteria in deposits.

\section{Protozoa and Algae}

The species of protozoa and naviculoid diatoms have in most cases been known by numbers. Taxonomic studies have been omitted, as these would have very much enlarged the scope of the work. Some ten species of flagellates, three species of amoebae, two of ciliates and about twenty species of diatoms occurred regularly in the cultures and showed fairly consistant behaviour. It was usual for about 40-50 species in all to be present in the mixed cultures of the dilution series. To this must be added the bacteria developing in these cultures. It is therefore not surprising that irregular gaps in the dilution series, due to culture failure, were apt to occur, especially among forms developing late.

The general sequence of events in one culture dish was as follows:

(I) Bacteria developed rapidly during the first week.

(2) The small colourless flagellates were present at the end of the first weekspp. II, IV, V (see p. 529 and Fig. 2).

(3) These were soon followed by another group of colourless flagellates-spp. VI, VII, XI, XII.

(4) Meanwhile planktonic diatoms were rapidly increasing and reached a maximum about the second or third week according to the light intensity. They then decayed.

(5) This gave rise to abundant organic matter, causing a further increase in the bacterial population. Most of the first group of small colourless flagellates had by this time died down, but not infrequently spp. II, IV and V persisted and were very abundant.

(6) Another group of flagellates, some containing coloured food vacuoles appeared about the third week. These (spp. I, XX, X and others) were rather larger than the first group.

(7) Amoebae were occasionally found early in the month, but they did not become abundant until there was plenty of plant debris. Some appeared to feed directly on the plant debris while others contained bacteria in their food vacuoles.

(8) During the decay of the planktonic diatoms, naviculoid diatoms and species of Nitzschia and Gyrosigma developed and usually remained active until well after the fourth week. In the winter months with low light intensity these bottom diatoms were conspicuous earlier in the sequence. Probably their compensation point (the light intensity at which the rate of photosynthesis and respiration are equal) is much lower than that of the planktonic forms.

(9) Ciliates only occurred at the more concentrated end of the series. They usually appeared early and were persistent.

(I0) If coloured flagellates occurred, it was towards the end of the month. These were probably members of the nannoplankton.

(II) After prolonged standing occasional red, green or brown algae developed, presumably from spores of littoral species.

Under the term 'bottom diatoms' are included pennate species, mainly naviculoids, which are not normally part of the net plankton. Varieties of Nitzschia closterium have been present so constantly that they have been included, though possibly they should be regarded as tychopelagic. Other 
tychopelagic forms, such as Paralia sulcata have been included with the planktonic diatoms. The distinction drawn has been partly one of convenience, separating those species which develop early in the cultures and were generally found in suspension from those which developed more slowly and usually crawled on the bottom. Members of this latter group were the only diatoms to develop under conditions of low light intensity. On account of its good growth in poor illumination, it is reasonable to include $N$. closterium with the bottom forms. The following species of planktonic diatoms occurred frequently in the cultures: Thalassiosira gravida, Th. nana, Sceletonema costatum, Chaetoceros spp., Asterionella japonica, etc.; the Rhizosolenia spp. were for the most part conspicuous by their absence. These species of planktonic diatoms did not reflect the changes in species seen in net plankton hauls made regularly over the Rame station. This discrepancy may be due to culture conditions, to the development of some species from resting spores independently of the season, to the hardiness of the vegetative cells of a few species, or possibly to some selective consumption by the zooplankton.

Some of the organisms mentioned above closely resembled species previously described, but identification is tentative. Others, while they cannot be named, were readily recognized by their characteristic behaviour and simple morphology:

FLAGellates.

II resembles Bodo angustus 8-I2 $\mu$ long, cf. Lemmermann (I9I4).

IV is a Monas sp. $4-6 \mu$ long.

$\mathrm{V}$ is a Bodo sp. $4-5 \mu$ long.

VI is a Choanflagellate $4 \mu$ long.

VII resembles Rhynchomonas nasuta $5 \mu$ long, cf. Griessmann (I9I4).

$\mathrm{XI}$ resembles Rhynchomonas mutabilis Io $\mu$ long, cf. Griessmann (I9I4).

$\mathrm{XII}$ is a Bodo sp. $2-3 \mu$ long.

I is a Bodo sp. I6 $\mu$ long, flattened.

$\mathrm{X}$ resembles Telonema subtilis 6-8 $\mu$ long, cf. Griessmann (I9I4).

Amoebae. Normal types, 5-IO and $15-30 \mu$ diameter (excluding pseudopodia) and limax type $c a$. I6 $\mu$ long.

HeliozoA. An occasional species, $c a .5 \mu$ diameter.

Ciliates. Uronema marinum, 20-25 $\mu$ long, cf. Kahl (1935).

Lembus pusillus, 20-30 $\mu$ long, cf. Kahl (1935).

Trochilia sp., I6-20 $\mu$ long, cf. Kahl (I935).

Mesodinium pulex, I5-20 $\mu$ long, cf. Kahl (1935).

Hypotrichous species up to $50 \mu$ long.

Several of these species are by no means restricted to the bottom habitat, they have been cultured from water samples and some have been found on a sandy shore. From Lackey's list of protozoa, classified according to habitatfloating, attached or in debris and on the bottom-it seems possible that some of the protozoan species may be only casual inhabitants of the bottom. In culture many of the flagellates and ciliates swim freely in the water, and it should not be supposed that individuals are necessarily confined to the deposit under natural conditions. 


\section{Results of Culture Census of the Microbenthos}

The following tables summarize the results ${ }^{1}$ of sampling between January and June 1939. Samples taken previously, while the technique was being standardized, are (so far as can be judged) in reasonable agreement with these later results. The comparisons given in Tables I-IV are based on minimal numbers, and the figures always indicate the order of magnitude of the numbers and quantities involved rather than their exact values. Of these organisms the bacteria, protozoa and some of the bottom diatoms may be regarded as constituting the true microbenthos. The planktonic diatoms are best regarded as a part, and probably only a small part, of the deposition on the bottom, which with detritus forms the main food supply of the benthos. Attention is again drawn to the limitations of the methods here employed (see p. 527). The results are still tentative, as there has not been sufficient opportunity to confirm any of the conclusions, which for the present are made on single or relatively few estimations.

\section{Horizontal Distribution}

Table I records the results of an attempt to investigate the local horizontal variations in numbers. The samples were taken on 24 January. Numbers per gram of dry mud from the top $\frac{1}{2} \mathrm{~cm}$. layer from the surface of five tubes are compared with those from another five tubes. The cores were grouped at random from a set of samples taken at the Rame station. Some part of the

TABLE I. Horizontal Variation

\begin{tabular}{|c|c|c|c|c|c|c|}
\hline & \multicolumn{3}{|c|}{ Cores I-5 } & \multicolumn{3}{|c|}{ Cores 6-Io } \\
\hline & $\begin{array}{l}\text { No. } \\
\text { of } \\
\text { spp. }\end{array}$ & $\begin{array}{l}\text { No. per } \\
\text { g. dry } \\
\text { mud }\end{array}$ & $\begin{array}{l}\text { Vol. of proto- } \\
\text { plasm in c.mm. } \\
\text { per g. of dry mud }\end{array}$ & $\begin{array}{l}\text { No. } \\
\text { of } \\
\text { spp. }\end{array}$ & $\begin{array}{l}\text { No. per } \\
\text { g. dry } \\
\text { mud }\end{array}$ & $\begin{array}{l}\text { Vol. of proto- } \\
\text { plasm in c.mm. } \\
\text { per g. of dry mud }\end{array}$ \\
\hline Bacteria (plate count) & $?$ & 345,000 & 0.0003 & $?$ & $2,050,000$ & 0.002 \\
\hline Ciliates & 2 & I5 & 0.0001 & 2 & & 0.0003 \\
\hline Amoebae & 4 & 2,335 & 0.0013 & 4 & 6,160 & 0.005 \\
\hline Flagellates & I7 & 14,900 & 0.0028 & I3 & 79,080 & 0.015 \\
\hline Bottom diatoms & II & 16,440 & 0.0046 & I0 & 46,270 & 0.0049 \\
\hline $\begin{array}{l}\text { Planktonic diatoms } \\
\text { and algae } \\
\text { Total vol. of living }\end{array}$ & matte & 21,140 & $\begin{array}{l}0.0083 \\
0.017 \mathrm{c} . \mathrm{mm}\end{array}$ & I8 & 49,000 & $\begin{array}{l}0.007 \\
0.035 \text { c.mm }\end{array}$ \\
\hline
\end{tabular}

difference in the total number of bacteria and of protozoa per gram may be due to the fact that rather less mud was taken off the surface of the cores 6-Io than off cores $\mathrm{I}-5$, there being probably some vertical gradation in abundance. Even if bacteria and protozoa were entirely concentrated in the extreme surface, irregularities of depth of sampling could not make the numbers per gram in cores 6-IO as much as twice those in I-5. Therefore there must be very considerable local variations, particularly among flagellates and bacteria. Diatoms are much more evenly distributed; this fairly even distribution has been confirmed in another count of diatoms alone. In subsequent comparisons

1 Full tables, illustrating the method of calculating the results (see p. 526), are available in a thesis placed in the Cambridge University Library and in the Library of the Marine Biological Association. 
ten cores were mixed, and it is hoped that local irregularities of distribution were thereby eliminated. Owing to difficulties of sampling it was not practicable regularly to obtain more cores.

\section{Vertical Distribution}

Table II summarizes the results of a comparison of the micro-organisms found in the surface $\frac{1}{2} \mathrm{~cm}$. layer of mud at the Rame station with those found at a depth of $2.5-3.0 \mathrm{~cm}$. in the same cores. The sample was taken on 27 April.

\section{TABLE II. VeRTICAL VARIATION}

\begin{tabular}{|c|c|c|c|c|c|c|}
\hline & \multicolumn{3}{|c|}{ Surface, $0-0.5 \mathrm{~cm}$} & \multicolumn{3}{|c|}{ Deeper layer, $2.5-3.0 \mathrm{~cm}$. } \\
\hline & $\begin{array}{l}\text { No. } \\
\text { of } \\
\text { spp. }\end{array}$ & $\begin{array}{l}\text { No. per } \\
\text { g. dry } \\
\text { mud }\end{array}$ & $\begin{array}{l}\text { Vol. of proto- } \\
\text { plasm in c.mm. } \\
\text { per g. of dry mud }\end{array}$ & $\begin{array}{l}\text { No. } \\
\text { of } \\
\text { spp. }\end{array}$ & $\begin{array}{l}\text { No. per } \\
\text { g. dry } \\
\text { mud }\end{array}$ & $\begin{array}{l}\text { Vol. of proto- } \\
\text { plasm in c.mm. } \\
\text { per g. of dry mud }\end{array}$ \\
\hline Bacteria (plate count) & ? 12 & 710,000 & 0.0007 & ? 12 & $\mathrm{I} 45,000$ & 0.00015 \\
\hline Ciliates & 2 & 12 & 0.00003 & I & 7 & 0.00007 \\
\hline Amoebae & 3 & 6,850 & 0.0005 & 2 & 230 & 0.0003 \\
\hline $\begin{array}{l}\text { Flagellates } \\
\text { Total protozoa }\end{array}$ & 15 & $\begin{array}{l}49,800 \\
(56,660)\end{array}$ & 0.0034 & IO & $\begin{array}{c}2,840 \\
(3,080)\end{array}$ & $0.0018^{\star}$ \\
\hline Bottom diatoms & I3 & II 8,090 & 0.012 & 8 & 34,160 & 0.0025 \\
\hline $\begin{array}{l}\text { Planktonic diatoms } \\
\text { and algae }\end{array}$ & I3 & 346,420 & 0.33 & 12 & 23,940 & 0.0079 \\
\hline Total vol. of living & matter & & $0.35 \mathrm{c} . \mathrm{mm}$. & & & 0.013 c.mm. \\
\hline
\end{tabular}

* The full tables show that the volume of flagellate protoplasm at the lower depth is almost entirely due to the presence of relatively few large dinoflagellates belonging to a single species ( $4 \%$ of the total number of flagellates giving rise to $90 \%$ of the volume). It is most unlikely that this species was in an active state when buried. If it were omitted from the list or a volume smaller than that of the active vegetative cell used in the calculations, the volume of flagellate protoplasm in the deeper layer would be much smaller than that in the surface layer. This is in better agreement with the numerical differences.

The surface layer is seen to be much richer in all groups than is the layer deeper in the core. It is obvious that planktonic diatoms contribute by far the greatest bulk to the total volume of living matter, especially on the surface. It is this rich layer which is of particular importance to many detritus eaters.

\section{Seasonal Variations}

Seasonal variations in the numbers of diatoms present in the surface layer were followed from winter to summer conditions. Variations in the numbers of protozoa could not be considered as seasonal variations since there were obviously large local variations, the greatest difference between samples being that shown in Table I. It is possible that there may be short-period fluctuations in numbers of protozoa and bacteria similar to those found in the soil by Cutler et al. (I922), but no attempt was made to investigate this point.

Separate stages in the changes in abundance from winter to spring and summer conditions are not significant, but the general drift is significant. There is a fourfold increase in numbers of bottom diatoms, and they are of considerable importance in the winter. Owing to the very great rise in the number and the greater bulk of planktonic species, these become overwhelmingly important in the spring and summer. 
Hunt stated that bottom diatoms ' have been found in sufficient quantity in the stomachs of various animals to suggest that they contribute a very important ultimate food factor for the animals of such a region'. The lack of

\section{Table III. Seasonal Variations in the Numbers of Diatoms}

All samples from the surface layer at the Rame station.

\begin{tabular}{|c|c|c|c|c|c|c|c|c|c|c|c|}
\hline \multirow{2}{*}{\multicolumn{2}{|c|}{$\begin{array}{l}\text { Date } \\
\text { I939 }\end{array}$}} & \multicolumn{4}{|c|}{ Planktonic diatoms (P1.) } & \multicolumn{4}{|c|}{ Bottom diatoms (B.) } & \multirow{2}{*}{$\begin{array}{l}\text { Total } \\
\text { vol. of } \\
\text { proto- } \\
\text { plasm } \\
\text { per g. }\end{array}$} & \multirow[b]{2}{*}{$\begin{array}{l}\text { Ratio } \\
\text { of vol. } \\
\text { Pl. : B. }\end{array}$} \\
\hline & & $\begin{array}{l}\text { No. of } \\
\text { spp. }\end{array}$ & $\begin{array}{l}+\mathrm{ve} \\
\text { pl. }\end{array}$ & $\begin{array}{l}\text { No. per } \\
\text { g. }\end{array}$ & $\begin{array}{l}\text { Vol. per } \\
\text { g. }\end{array}$ & $\begin{array}{l}\text { No. of } \\
\text { spp. }\end{array}$ & $\begin{array}{l}\text { +ve } \\
\text { pl. }\end{array}$ & $\begin{array}{l}\text { No. per } \\
\text { g. }\end{array}$ & $\begin{array}{l}\text { Vol. per } \\
\text { g. }\end{array}$ & & \\
\hline 24 Jan. & $\left\{\begin{array}{l}a \\
b \\
c\end{array}\right.$ & $\begin{array}{l}\text { I3 } \\
\text { I5 } \\
\text { I5 }\end{array}$ & $\begin{array}{l}52 \\
51 \\
55\end{array}$ & $\begin{array}{c}26,000 \\
16,000 \\
48,000\end{array}$ & 0.0083 & $\begin{array}{r}\text { II } \\
8\end{array}$ & $\begin{array}{l}54 \\
34 \\
\end{array}$ & $\begin{array}{r}26,000 \\
6,400\end{array}$ & 0.0046 & $\left.\begin{array}{l}0.013 \\
0.013\end{array}\right\}$ & $I \cdot 7: I$ \\
\hline 6 Mar. & $\left\{\begin{array}{l}d \\
e\end{array}\right.$ & $\begin{array}{l}15 \\
15 \\
16\end{array}$ & $\begin{array}{l}50 \\
74 \\
67\end{array}$ & $\begin{array}{r}48,000 \\
71,000 \\
178,000\end{array}$ & $\begin{array}{l}0.0076 \\
0.026 \\
0.048\end{array}$ & $\begin{array}{l}\text { I0 } \\
\text { I2 } \\
\text { IO }\end{array}$ & $\begin{array}{l}42 \\
46 \\
49\end{array}$ & $\begin{array}{l}46,000 \\
\text { I } 4,000 \\
\text { I I,000 }\end{array}$ & $\left.\begin{array}{l}0.0049 \\
0.0042 \\
0.0049\end{array}\right\}$ & 0.042 & $8: I$ \\
\hline I6 Mar. & $f$ & I4 & 60 & I96,000 & 0.030 & I 2 & 70 & 99,000 & 0.015 & 0.045 & $2: I$ \\
\hline 3 Apr. & $g$ & I7 & 69 & I I 2,000 & 0.19 & 12 & 66 & 84,000 & 0.018 & 0.21 & IO : I \\
\hline 27 Apr. & $h$ & 13 & 80 & 364,000 & 0.33 & I4 & 65 & I I 8,000 & 0.012 & 0.34 & $33: 1$ \\
\hline 3I May & $i$ & 15 & 75 & 604,000 & $I \cdot 28$ & II & 54 & I 56,000 & 0.019 & $I \cdot 30$ & $67: I$ \\
\hline
\end{tabular}

$a$ and $b$, each from five cores (see Table I).

$c$, from an independent culture series using mud from $a$ and $b$, from ten cores.

$d$ and $e$, each from five cores. $\quad f-i$, each from ten cores.

knowledge as to their abundance and seasonal variation in numbers has now to some extent been remedied. Owing to the lack of agreement between the planktonic species (see p. 529) occurring on the bottom and in the water, a detailed comparison cannot be made between the numbers deposited and the phytoplankton crop.

\section{Regional Distribution}

Samples were collected from different types of deposit and from various depths. A comparison was made between a Rame mud sample taken on I6 March and an Eddystone shell-gravel sample taken on I4 March, so that the cultures were running simultaneously in the same light intensity. The coarse deposit was collected with the Hunt vacuum grab, which takes an unstratified sample from an area of about $42 \mathrm{~cm} .{ }^{2}$ and to a depth of about $2 \mathrm{~cm}$. on sands and gravels. Figures are given per gram of total deposit, as in the probable absence of a distinct surface layer this is the form most comparable with the Rame figures. No bacterial estimation was made, because the Hunt grab in its present design is unsuitable for bacterial sampling. The number of bacteria per gram of total deposit is likely to be low in shell-gravel.

All groups are significantly less abundant in the shell-gravel than in the mud. A deposit-eating member of the shell-gravel fauna would, however, probably ingest only the fine particles; the proportion of living matter in this small silt fraction is quite as high as at Rame. Smith (1932) recorded the presence of animals feeding both selectively and non-selectively on bottom material and also, of course, of carnivores. Suspension feeders are, however, the members 
of the macrofauna most common on the Eddystone shell-gravels. The figures in Table IV indicate that there is an appreciable deposition of planktonic diatoms, and so presumably of other organic matter; water movement over the bottom will keep some of this material in suspension. It is possible that some of the organisms here recorded per gram of deposit were actually in suspension

Table IV. Regional Variation in Different Types of Deposit

\begin{tabular}{|c|c|c|c|c|c|c|}
\hline & \multicolumn{3}{|c|}{$\begin{array}{l}\text { Rame mud (regular station), } \\
\text { sample taken I6 March }\end{array}$} & \multicolumn{3}{|c|}{$\begin{array}{l}\text { Eddystone shell-gravel, } \\
\text { sample taken I4 March }\end{array}$} \\
\hline & $\begin{array}{l}\text { No. } \\
\text { of } \\
\text { spp. }\end{array}$ & $\begin{array}{l}\text { No. per } \\
\text { g. of dry } \\
\text { mud }\end{array}$ & $\begin{array}{l}\text { Vol. of proto- } \\
\text { plasm in c.mm. } \\
\text { per g. dry mud }\end{array}$ & $\begin{array}{l}\text { No. } \\
\text { of } \\
\text { spp. }\end{array}$ & $\begin{array}{l}\text { No. per } \\
\text { g. total } \\
\text { deposit }\end{array}$ & $\begin{array}{l}\text { Vol. of proto- } \\
\text { plasm in c.mm. } \\
\text { per g. dry deposit }\end{array}$ \\
\hline Ciliates & 2 & 30 & 0.0002 & 2 & 8 & 0.00003 \\
\hline Amoebae & 3 & 5,680 & 0.0033 & 3 & 680 & 0.00036 \\
\hline Flagellates & I2 & II,6I4 & 0.0013 & 6 & 600 & 0.000022 \\
\hline Bottom diatoms & 12 & $99,470^{\circ}-1$ & 0.015 & II & 7,680 & 0.007 \\
\hline Planktonic diatoms & 16 & 196,000 & 0.030 & 6 & 38,590 & 0.006 \\
\hline $\begin{array}{l}\text { and algae } \\
\text { Total vol. of livin } \\
\text { bacteria, per g. }\end{array}$ & $\begin{array}{l}\text { Ig ma } \\
\text { total }\end{array}$ & $\begin{array}{l}\text {, exclu } \\
\text { posit }\end{array}$ & 0.050 c.mm. & & & $0.013 \mathrm{c} . \mathrm{mm}$. \\
\hline
\end{tabular}

immediately over the bottom and brought up with the supernatant water which is unavoidably collected by the vacuum grab.

A few other samples, though not directly comparable with the preceding results, gave a preliminary indication of the distribution of diatoms on the bottom. Planktonic diatoms were much less frequent on coarser deposits seawards from the Rame station, and they were not found in sand on the shore at Wembury nor in the estuarine mud at Laira. Naviculoid diatoms had a surprisingly wide distribution in the sublittoral zone, at least during the summer. For example, Cocconeis sp. occurred quite abundantly with several other species as well, on the sandy bottom at Station E I, 20 miles from the land and at a depth of $72 \mathrm{~m}$., but under clearer water than at Rame. In a sample ${ }^{1}$ taken at the mouth of the English Channel (at $49^{\circ} 9^{\prime} \mathrm{N} ., 6^{\circ} 7^{\prime} \mathrm{W}$.) from a depth of II3 $\mathrm{m}$. no planktonic diatoms were found, only one large naviculoid diatom species developed in culture and a few other moribund cells of tychopelagic and bottom species were seen. Owing to the unavoidable delay of 6 days after sampling before examination and the setting up of cultures it is difficult to be certain of the reason for the dearth of plants, but it seems probable that the limit of active plant life on the bottom had nearly, if not quite, been reached at this station. The exact significance of the commonly accepted idea of a lighted benthic zone down to a depth of about $100 \mathrm{fm}$. (the sublittoral zone) needs more thorough investigation.

\section{The Quantity of Microbenthos relative to the total Organic Matter in the Deposit}

In order to assess the contribution that the microbenthos makes to the total food supply available to the detritus-eating macrofauna an estimate would have to be made of the absolute population density. Since this is at present

\footnotetext{
${ }^{1}$ Kindly taken for me by Mr G. A. Steven.
} 
impossible, an arbitrary method has been employed of obtaining from the culture census figures something more nearly approaching a maximal value for the population. From this extremely rough approximation it has been estimated that, if the organic carbon at Rame be taken as I g. in Ioo g. dry mud, then in the surface $\frac{1}{2} \mathrm{~cm}$. layer only about $0.3-0.03 \%$ of this carbon is derived from bacteria, protozoa and bottom diatoms; at least a further $2.5-0.015 \%$ comes from recently deposited and still living planktonic diatoms, according to the season. At a depth of $2.5-3.0 \mathrm{~cm}$. below the mud surface, a single sample indicated that only about one-fifth of the volume of microbenthos was present compared with that at the surface, and probably there would be even smaller quantities at greater depths.

\section{Comparison with other Habitats.}

Some of these results are supported by comparison with those of other workers. Data from the western Atlantic coast given by Reuszer (I933) show the richness of the bacterial population in the extreme surface layer of a mud deposit compared with the numbers present at a depth of $2.5 \mathrm{~cm}$. in the mud and with those found in the top $2.5 \mathrm{~cm}$. of a sand deposit. The organic content of the mud was considerably greater than that at Rame, but despite this the numbers of bacteria were of the same order in the two habitats. Reuszer found up to a hundredfold variation between the bacterial content of different cores and concluded that dense aggregations of bacteria might be associated with recently deposited organic matter. Lackey (1936) gave figures which showed the richness of the protozoan fauna associated with freshly deposited detritus, and in stressing the importance of the surface layer of mud for the activities of the protozoa, stated that the surface of mud cores from shallow water contained 'an abundance of flagellates and ciliates', whereas samples from a sandy bottom yielded few protozoa. Remane (1933), on the other hand, in comparing the number of species of ciliates in sand and mud deposits in the shallow waters of Kiel Bay (maximum depth $20 \mathrm{~m}$.) found very few ciliates in the mud. It is, however, probable that the black mud there was of a stickier consistency than that at Rame. The sand habitat in Kiel Bay contained many species of ciliates, but the population density is unknown. On this sand there was a rich flora of bottom diatoms.

In freshwater deposits Moore (1939) found by direct examination that protozoa were most numerous in the top centimetre of the cores and that the numbers decreased rapidly to extinction at about $5 \mathrm{~cm}$. below the surface on 'muck' bottoms. Pennak (1940) made brief mention of the micro-organisms found in a sandy beach of a large freshwater lake: in general composition and in the importance of ciliates, coloured flagellates and also rotifers, there was considerable similarity to the microbenthic community found in sand on the sea shore at Wembury. Micro-organisms present in arable soil at Rothamsted (see Cutler et al. 1922) were more numerous than in the Rame deposit, a 
difference possibly associated with the smaller amount of available organic matter in the sea bottom. Groups occurred in the same order of abundance (bacteria, flagellates, amoebae and ciliates) in both habitats, but when account is taken of size the amoebae were possibly relatively more important than flagellates in the soil, whereas there was more nearly an equality of volumes of these two groups in the Rame deposit.

\section{Food Relationships}

Diatoms have been shown to constitute a large part of the microbenthic community. It is important to consider whether or not they are able to photosynthesize when on the bottom. Jenkin (I937) found that the compensation point for Coscinodiscus excentricus (a planktonic diatom requiring low light intensity) was at $45 \mathrm{~m}$. in July near the Eddystone, over cleaner, sandier ground than the Rame station. In Jenkin's experiments the light intensity at $45 \mathrm{~m}$. was about $0.5 \%$ of that at the surface. Poole \& Atkins (I929) found the light intensity very close to the sandy bottom, at $70 \mathrm{~m}$. at station $\mathrm{E} \mathrm{I}$, in March, April and May to be respectively 0.016, 0.098 and 0.121 \% of that at the surface; on this deposit (sampled in May) a small naviculoid, Cocconeis sp., was found to be abundant. In the immediate neighbourhood of the bottom over mud there must be a rapid decrease in light intensity. It is therefore probable that there is little or no production by planktonic diatoms in the vicinity of the bottom at the Rame station. Since bottom pennate diatoms have a lower compensation point than planktonic species it seems probable that sufficient photosynthesis for net production can be carried on by bottom diatoms when lying on the extreme surface and to a greater extent when they are washed into suspension. These diatoms may be buried by falling debris or by disturbances of the bottom due to the epifauna or burrowers, but since most bottom diatoms are motile some will regain the surface. Small coloured flagellates have also been found on the bottom, but it is thought that they are really members of the nannoplankton, and nothing is known of their light requirements.

Some deductions concerning the food habits of protozoa, when under culture conditions, can be made from observations on the dishes of the dilution series and from other cultures. It was observed for instance that both Uronema marinum and Lembus pusillus throve in pure cultures on a diet of bacteria, but that in the mixed cultures of the dilution series, while Uronema marinum continued to feed almost exclusively on bacteria, Lembus pusillus nearly always had coloured food vacuoles, containing the remains of diatoms or coloured flagellates. Thus it seems that these two ciliates differ in their food preferences. To what extent such preferences would be apparent in the natural environment would be dependent on the relative abundance of bacterial and plant food. Both ciliates probably ingest detritus. A large Bodo species was observed on one occasion to have been ingesting numerous small chlamydomonads, but generally the plant-eating flagellates and also ciliates and amoebae 
were dependent on diatoms already partially disintegrated by autolysis or bacterial action and flagellates have been observed ingesting chloroplasts inside frustules of decaying diatoms. Under natural conditions it is probable that these plant-eating forms are capable of subsisting on a variety of diets; possibly they require more abundant organic particles than do the smaller flagellates. The small flagellates mentioned in stages (2) and (3) of the culture series (p. 528) were observed to contain particulate food; they tended to remain on or near the bottom surface of the dish unless there was dead organic material in suspension. Some clearly showed aggregation round organic particles. It is thought that they are chiefly bacterial feeders and probably also saprophytic. Sandon (1932), while not doubting the possibility of saprophytic nutrition among the Protomastigina, does not regard it as definitely proved. Some of the colourless euglenids seen occasionally in these cultures may well be saprophytic. As far as is known amoebae always depend on the ingestion of solid food; the way in which they grazed the film of bacteria on the bottom of a Petri dish made patches of amoebae easy to detect with a dissecting microscope. Soil amoebae are known to show distinct preferences for various types of bacteria. Singh (I94I) has demonstrated such preferences in both pure mixed culture and in sterilized soil, but has found that the amoebae are not so destructive of edible species in the soil cultures. This further illustrates that predator-prey relationships may well be quite different when 'refuges' are present, as was shown by Gause (1934).

The interaction of protozoa and bacteria may be of importance in several ways in the turn-over of organic matter in a deposit. The predatory activities of amoebae and ciliates may exert a marked influence on the bacterial numbers, depending on the relative volumes and rates of reproduction of the predators and prey. These predatory activities, if excessive, would decimate the bacterial population. They may, however, only be sufficient to keep the bacterial numbers at or near such a level that each bacterial cell exhibits its maximum chemical efficiency; such an effect has been found by Cutler \& Crump (1929) and by Meiklejohn (1930, 1932) with pure cultures of bacteria and soil amoebae or ciliates. Protozoa and bacteria may compete for available organic matter, either dissolved or particulate (see Fig. 2, legend).

Great care must be exercised in deducing from results of culture experiments any relationships in the natural habitat. In cultures here set up no attempt was made to reproduce exactly the natural conditions. A culture dish of the dilution series was an isolated habitat with only very sparse mud particles. It usually had a large initial supply of organic food followed by the naturally produced abundant plant food, which resulted from a light intensity far in excess of that in the natural habitat. When small doses of organic food were added at weekly intervals the protozoan culture succession was delayed, though the additions were not accurately adjusted to maintain a balanced population. When cultures were grown under much reduced light intensities, thus approaching more nearly the natural conditions of the habitat, only a few 


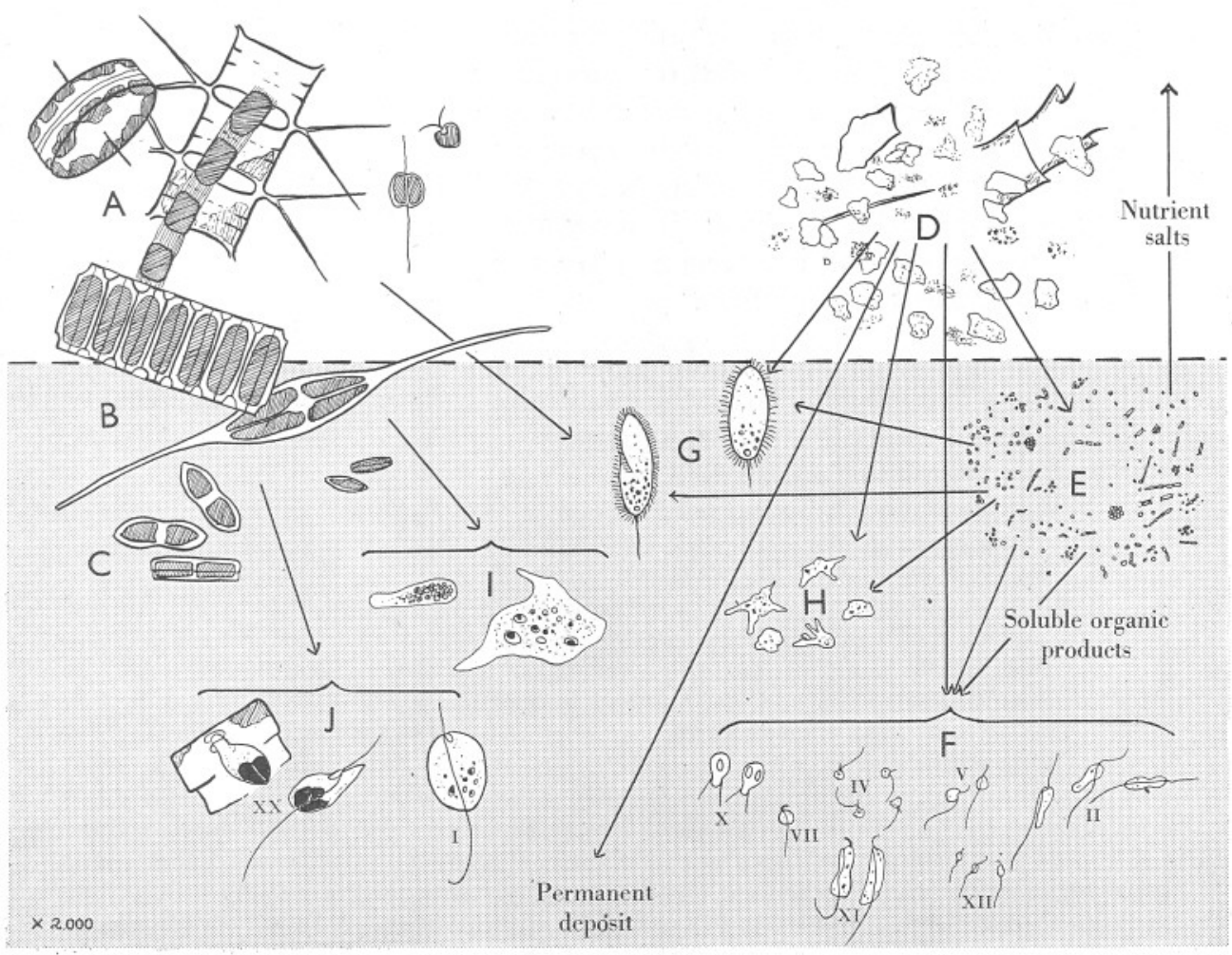

Fig. 2. Food chains in the microbenthos. This diagram represents probable food relationships between supplies dropping from the water and organisms in the surface layer of the mud. The organisms represented are mentioned on pp. 528 and 529 and are drawn to scale ( $\mathrm{I} \mathrm{mm.}$ $=2 \mu$ ). Relative abundance cannot be adequately represented. A. Phytoplanktondiatoms and coloured nannoplanktonic flagellates. B. Tychopelagic diatoms. C. Bottom naviculoid diatoms. D. Detritus - animal and plant remains and faecal material already disintegrated and partly decomposed in the water. E. Bacteria-by means of extracellular enzymes they utilize detritus, converting part into their own protoplasm, liberating nutrient salts to the water, and freeing some soluble organic matter which may be used by other bacteria or by flagellates. F. Small colourless flagellates-they ingest bacteria and possibly detritus and may also live saprophytically. G. Ciliates-Uronema marinum is known in culture to digest bacteria and probably also takes detritus. Lembus pusillus ingests bacteria and if plant remains are abundant, has many coloured food vacuoles. H. Small amoebae-bacterial feeders, probably also ingesting detritus. I. Amoebaea large normal and a limax type are often seen with coloured food vacuoles, they probably also take other types of food. J. Large colourless flagellates-with coloured food vacuoles, one is shown inside a dead diatom. Plant-eating protozoa cannot ingest whole diatoms, but depend on fragments produced by autolysis and bacterial action. The resistant residues of detritus are permanently buried in the mud. 
naviculoid diatoms developed and the growth of planktonic species was prevented.

It is clear that the groups of the microbenthos are by no means independent of each other. Only the broadest outlines of qualitative relationships in the habitat are suggested in Fig. 2. A determination of the relative abundance (see pp. 530-533) and of the rates of reproduction of the various species and characteristics of their behaviour under natural conditions are essential before further deductions can be made. It is suggested, however, that the possible influence of protozoa in the nitrogen cycle or in regeneration of phosphates in the sea should not be overlooked.

\section{Summary of the Activities of the Microbenthos}

It is helpful here to summarize the qualitative knowledge of the activities of the microbenthos in the turn-over of organic matter in a sub-littoral habitat. These activities may be subdivided as follows:

(I) Production of organic matter from inorganic compounds.

(a) Chemosynthesis by bacteria is known to play a part on the bottom (see ZoBell, 1939).

(b) Photosynthesis. The activity of the bottom diatoms will obviously depend on the light intensity, varying with the season and with the depth and clearness of the water. It is thought probable that there is some production, at least in the spring and summer, on the bottom at the Rame station.

(2) Conversion of organic matter from one form to another is chiefly carried out by bacteria. They change indigestible forms such as chitin (see ZoBell \& Rittenberg, I938) or celluloses into more digestible bacterial protoplasm. ZoBell \& Feltham (1938) and MacGinitie (1932) have proved that some bacteria may serve as food for metazoa, and it is known that they are an important food for protozoa. The bacteria, however, also utilize the more available fractions of the organic detritus in their own metabolism, leaving indigestible residues known as marine humus (Waksman, I933).

(3) Accumulation of soluble organic matter as protoplasm by bacteria and saprozoic protozoa is certainly an advantageous process for the metazoa. On the other hand, the concentration of small food particles by protozoa, though of possible advantage to metazoa obtaining food by filtration of large volumes of water, is an extravagant process in a mud habitat, because the protozoa themselves consume some of the organic matter which they accumulate and a deposit feeder ingests all small particles in whatever size or form they may be.

(4) Consumption of organic matter. All the microbenthos respire, and except for some of the bacteria involved in the nitrogen and sulphur cycles, they derive their energy from the oxidation of organic matter, whether it be external to them or their own protoplasm.

\section{The Total Fauna and Flora per unit area of the Rame Habitat}

A brief census was attempted of organisms of all sizes in a unit area of the Rame deposit, in order to place the quantity of the microbenthos in perspective with that of the larger fauna. This has only been partially achieved. The sampling has not been extensive enough to include satisfactorily the larger, scarcer members of each size group, nor has it been possible to take more than a few samples to determine the approximate abundance of the macro- and meiobenthos. Of the macrofauna only the infauna were collected. 
The numbers and weights of the organisms present give a picture of the population at one time. Investigations of the type of food consumed link together the members of the community. To assess their relative importance in the turn-over of organic matter, it would be necessary to know their respiratory rates throughout the year, i.e. their rate of oxidation or consumption of organic matter. In considering the quantity of food which any one of the smaller groups may be providing for consumption by the larger fauna, the relative rates of growth and reproduction must be taken into account. This line of approach has been followed by previous ecologists, who stressed these important considerations (see Petersen, I918; Boysen Jensen, 1919; Bornebusch, 1930; Thamdrup, 1935; and Krogh \& Spärck, 1936). With the exception of Lohmann (1908, I9I I) they have usually confined their attention to one or two size groups.

\section{The Meiobenthos}

Only a few core samples were examined to gain an approximate idea of the abundance of nematodes, harpactacid copepods, foraminifera, etc. Small crustaceans are known sometimes to leave the bottom and were occasionally seen to migrate up the sample tubes; the census includes all those which were taken in the sample tubes. In Table $\mathrm{V}$ are given the results of examination of sieved mud from two sets of samples taken (a) on I6 March 1939, and (b) on 3I May 1939.

\section{Table V. Numbers and Depth Distribution of Meiobenthos}

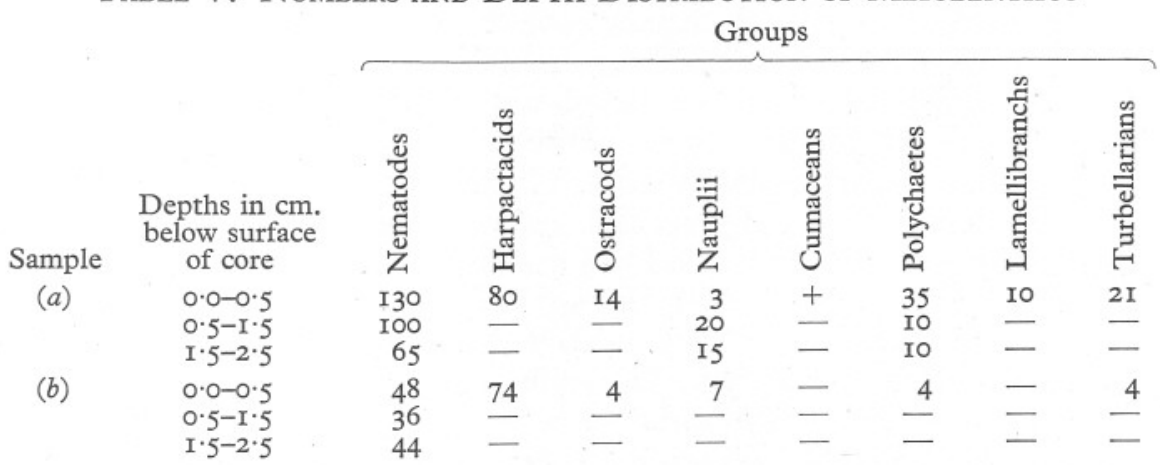

Table $\mathrm{V}$ shows the greatest abundance of animals to be in the surface $\frac{1}{2} \mathrm{~cm}$. layer and the restriction of adult harpactacids to that layer; nematodes and very small polychaetes were the dominant organisms deeper in the cores. Living foraminifera were entirely restricted to the extreme surface layer and were not very abundant relative to the rest of the meiobenthos (Dr E. H. Myers, personal communication).

These observations of the numbers and distribution of the small fauna are in reasonable agreement with the findings of Moore (193I) in the Clyde and Krogh \& Spärck (1936) in Copenhagen Sound. 
Satisfactory determination of the true live weight of these small animals is not easy. The following procedure was adopted: 50-70 copepods were placed on a cover-slip and the animals were counted while as much as possible of the extraneous water was removed with a fine pipette. They were weighed quickly; the animals were then picked off with a needle, leaving salt crystals and any debris on the cover-slip, which was then weighed again. The chief errors were due to the presence of extraneous water and to loss by evaporation from the animals themselves; these errors may be large but they oppose each other. The method was tested by weighing some larger copepods-Tigriopus sp.- the true density of which had previously been determined by $\mathrm{Mr} \mathrm{A}$. G. Lowndes (to whom I am much indebted for permission to use his data and material). Determinations of the density on two samples had given the average weight of an individual as 0.042 and $0.039 \mathrm{mg}$. and direct weighings gave 0.043 and 0.04I mg. The results from the two methods agreed better than was expected. The density method is only applicable when small animals can be obtained in very large numbers free from debris. A supply of copepods and nematodes was derived from Laira, where they were of similar size to those occurring at Rame. The average weight of these copepods was $0.005 \mathrm{mg}$. each and the nematodes $0.003 \mathrm{mg}$. each. From the Rame habitat, less satisfactory determinations (made on fewer animals and when evaporation from the animals was strongly suspected) gave values of $0.0024 \mathrm{mg}$. each for copepods and $0.0017 \mathrm{mg}$. each for nematodes. Turbellarians disintegrated during preparation for weighing; it was judged by inspection that they would be about the same average weight as the nematodes and that polychaetes would be appreciably heavier. The total weight of the Rame meiobenthos given in Table IX has been estimated on the basis of the individual weights of animals obtained from Laira; it is therefore an extremely rough and temporary approximation. Krogh \& Spärck (1936) gave figures for the 'microfauna' from which can be calculated the average weight of copepods, $0 . \mathrm{I}-0.135 \mathrm{mg}$. each and of nematodes, $0.1 \mathrm{mg}$. each. The relative weights are similar to the Laira and Rame values, but if these organisms are the same size in the three habitats it is very tentatively suggested that perhaps there is some error in their computation, presentation of data or in the determination of the wet weight. The values for all the groups are very high, and the weight given for 'Infusoria' ( $0 \cdot 45^{-1} \cdot 0 \mathrm{mg}$. each) seems impossible.

For its food supply the meiobenthos is dependent on detritus, on the microbenthos and on other members of its own group. The little that is known of the food and feeding habits is tabulated below, with the sources from which the information was obtained.

$\begin{array}{lll}\text { NEMATODES. } & \begin{array}{l}\text { Guts often empty, occasionally containing a } \\ \text { little fine silt and possibly organic particles } \\ \text { Ingest the whole of the substrate in fresh- } \\ \text { water muds } \\ \text { Carnivores, detritus eaters and diatom } \\ \text { eaters }\end{array} & \text { Baier (I935) } \\ \text { OstracoDs. } & \begin{array}{l}\text { Probably mainly mud eaters } \\ \text { Remane (1933) }\end{array} & \text { Remane (1933) }\end{array}$


TURBellarians. May prey on nematodes

HARPACTACID COPEPODS.

FORAMINIFERA. mass in hind-gut of food
No recognizable particles in amorphous

Probably scavengers and carnivores, being quite capable of chewing selected pieces

Solid particles ingested by Miliolidae

Some ingest solid particles, while others will grow on a diatom food supply but appear to feed by external digestion
Remane (1933)

Own observation and from Mr R. Elmhirst

Mr A. G. Lowndes, personal communication

Own observation

Dr E. H. Myers and Dr M. W. Jepps, personal communications

\section{The Macrobenthos}

A brief investigation of the macrofauna of the Rame station has been made, and it may be amplified by the earlier survey of the region by Ford. The station lies nearest to his station no. 93 (see Chart to face p. 167, Ford, 1923). The community is very similar to that illustrated on p. 184 of his paper. Observations on feeding habits of macrofauna in this region were made by Hunt (I925).

Hauls were made with a Petersen grab on I2 July I939, and the material washed through a piece of stramin netting which proved to be an effective method for the retention of the very numerous small polychaetes. Table VI

\section{Table VI. The Macrofauna of the Rame Deposit}

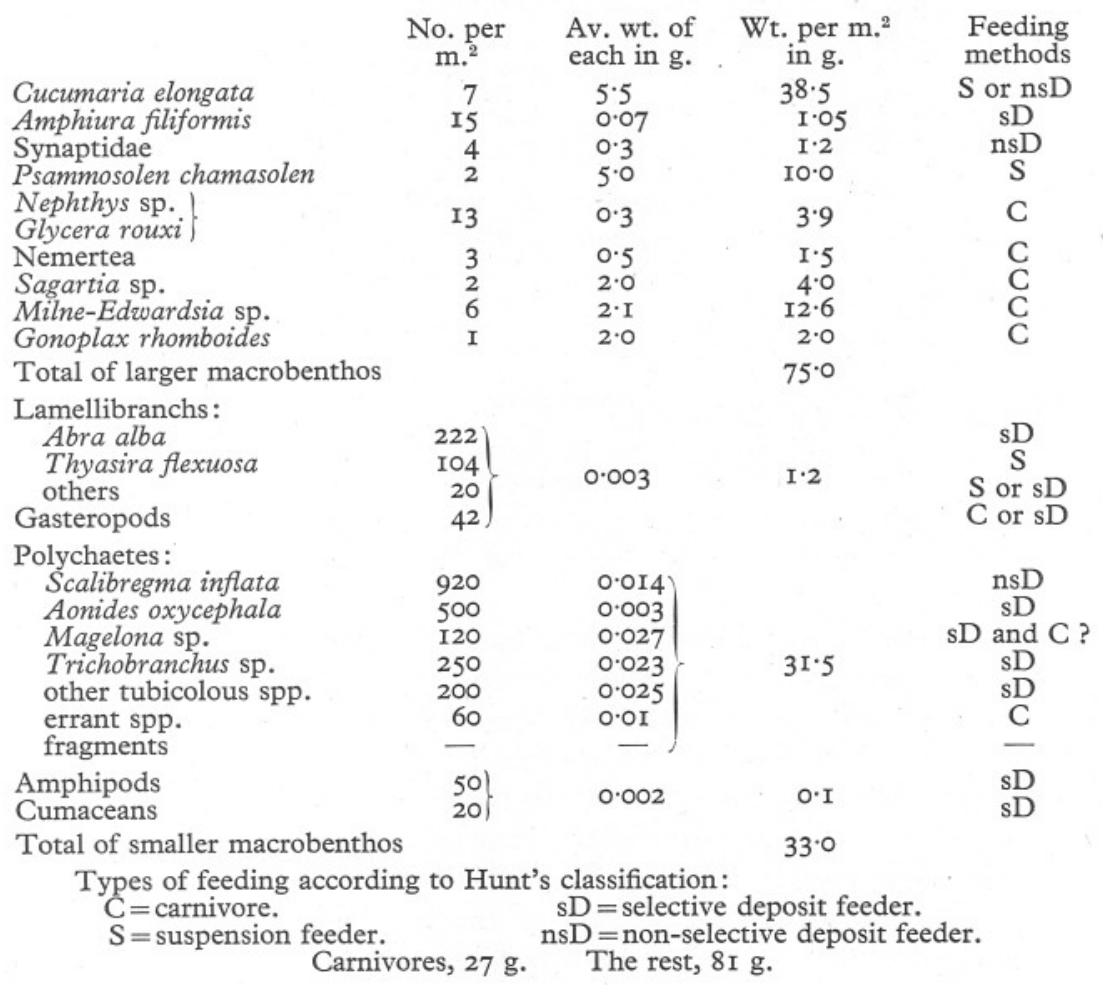


gives the numbers and weights per square metre. For the larger animals ten hauls, each from $0.1 \mathrm{~m} .{ }^{2}$, were examined, and for the smaller animals five of these hauls were searched. Living weights obtained by direct weighing are given. Since the average depth of the grab sample is about $10 \mathrm{~cm}$. some of the rapidly burrowing crustacea will have been missed; it is known, for example, from dredge hauls that Callianassa subterranea is present at that station. Echinocardium cordatum was also found only in dredge hauls. Nomenclature is that used in the Plymouth Marine Fauna (I93I).

The great importance of small polychaetes in this area is clearly seen from Table VI. When generation time and potential reproductive capacity are borne

\section{Table VII. Polychaetes from the Rame Deposit}

(Sample collected I2 July 1939)

\begin{tabular}{|c|c|c|c|}
\hline & $\begin{array}{l}\text { No. per } \\
\text { m. }\end{array}$ & & $\begin{array}{l}\text { No. per } \\
\text { m. }{ }^{2}\end{array}$ \\
\hline Harmothoë longisetis (Grube) & r & Spionidae: indet. & \\
\hline Chiaje) & $\mathrm{r}$ & Aonides oxycephala (Sars) & 500 \\
\hline Sthenelais limicola (Ehlers) & $\mathrm{r}$ & †Magelona sp. & 120 \\
\hline Iroditidae: indet. & $\mathrm{r}$ & tulidae: indet. & 40 \\
\hline Phyllodoce sp. & $\mathrm{r}$ & Diplocirrus glaucus Haase & \\
\hline Eulalia sp. possibly $E$. sanguinea (Oersted) & $\mathrm{r}$ & Scalibregma inflatum Rathke & 920 \\
\hline Phyllodocidae: indet. & $\mathrm{r}$ & Ammotrypane aulogaster Rathke & 20 \\
\hline (1) & $\mathrm{r}$ & us latericus Sars & 0 \\
\hline Ophiodromus flexuosus Delle Chiaje & $\mathrm{r}$ & Owenia fusiformis Delle Chiaje & \\
\hline Nereis fucata (Savigny) & $\mathrm{r}$ & Pectinaria sp. & \\
\hline $\begin{array}{l}{ }^{\star} \text { Nephthys sp. possibly } N \text {. hystericis } \\
\text { McIntosh }\end{array}$ & 8 & $\begin{array}{l}\text { Ampharete grubei Malmgren } \\
\text { Amphicteis gunneri Sars }\end{array}$ & \\
\hline $\begin{array}{l}\text { Nephthys sp. probably young } N \text {. hombergi } \\
\text { Audouin \& M. Edwards }\end{array}$ & 8 & $\begin{array}{l}\text { Ampharetidae: indet. } \\
\text { Melinna palmata Grube }\end{array}$ & $\begin{array}{r}r \\
20\end{array}$ \\
\hline Glycera rouxi Audouin \& M. Edwards & Io & rebellides stroemi Sars & \\
\hline naculata Oersted & 25 & * Trichobranchus roseus Malmgren & 250 \\
\hline Lumbriconereis $\mathrm{sp}$. & $\mathrm{r}$ & *Streblosoma bairdi (Malmgren) & 70 \\
\hline *Drilonereis filum (Claparède) & $\mathbf{r}$ & Terebellidae: indet. tube only & \\
\hline
\end{tabular}

$\mathrm{r}=$ about $\mathrm{I}-5$ per $\mathrm{m}^{2}$, i.e. $\mathrm{I}-3$ specimens taken.

$\star=$ new record for the Plymouth area.

† Magelona sp. has been provisionally identified as $M$. cincta (Ehlers) by Mr D. P. Wilson, who is engaged on a description of it and its larva.

I am much indebted to $\mathrm{Mr} \mathrm{D}$. P. Wilson for correcting and amplifying this list, as far as possible with limited material. Several interesting species need further investigation.

in mind, the polychaetes appear even more important than is immediately obvious from the weights. Details of this part of the fauna are listed in Table VII. Juvenile forms were common, but many were mature specimens of small species. The list includes several new records for the Plymouth area.

An examination of the gut contents of the bottom fauna and of the morphology of their feeding apparatus throws some light on their feeding methods and the parts of the habitat from which food was derived. Hunt's observations have largely been confirmed. A summary of the more interesting and important data is given below and the types of feeding are also indicated in Table VI. 
Cucumaria elongata, whose weight in these samples comprised about a third of the total, may feed from material in suspension above the bottom but may also, according to Orton (I9I4), remain completely buried for long periods and presumably behave as a non-selective deposit feeder.

Scalibregma inflata is an important non-selective deposit feeder, which by means of its eversible pharynx ingests the surface or subsurface layers of the deposit. It may be of some importance in the habitat in transporting buried material to the surface. It occurred on the average at a density of one worm per II cm. ${ }^{2}$ of mud surface.

Melinna palmata, Trichobranchus roseus and Aonides oxycephala: the gut contents showed some selection of the finer grades of silt and occasional diatoms were found; this presumably indicates that they collect particles from the surface of the deposit by means of their ciliated tentacles.

Magelona sp, has a pair of tentacles armed with many small suckers. Besides silt, its gut contained fragments of small crustacea, indicating that the worm is in part either a carnivore or a scavenger. Larvae of Magelona are known to select lamellibranch larvae in the plankton (Lebour, I922).

Nephthys spp. and Glycera rouxi rarely had any gut contents; when present they consisted of the remains of other polychaetes.

Gonoplax rhomboides: one specimen had been feeding on polychaetes; the gastric mill of another contained fragments of small lamellibranchs and numerous Foraminifera-Quinquiloculina akneriana (= Miliolina seminulum) and Rotalia beccarii had been selected; these foraminiferan species were among the commonest living on the deposit.

LAMELLIBRANCHS: as shown by Hunt, some species feed from the surface of the deposit and others from material in suspension just above the bottom, the latter habit causing a conspicuous selection of diatoms.

From Table VI it will be seen that about $25 \%$ of the fauna is carnivorous, while the rest depends on deposited organic matter and possibly on the microorganisms associated with it. As pointed out by Hunt, the absence of recognizable remains of minute naked organisms is no proof that they are not ingested. Non-selective deposit feeders will ingest detritus and microbenthos and to some extent meiobenthos in the proportions in which they have been found in the general mass of mud. Selective deposit feeders, particularly those collecting material from the extreme surface, have access to rather more living and dead organic matter, while suspension feeders have a distinctly more nutritious food supply.

\section{Diagrammatic Summary of the Quantities of Organisms in the Rame Deposit}

The total population per unit area of the deposit is best summarized in a diagram. The diagram (Fig. 3 ) is intended to convey only the order of magnitude of the quantities of living matter present at one time and to illustrate a method of considering a population. It is built up from the few samples taken at various times from the Rame habitat and described in the preceding sections. It must be emphasized that the diagram is not by any means complete, first because the larger, and less frequent forms of each of the size groups have not been satisfactorily sampled, and secondly because the depth to which the samples have been taken is not sufficient to include all the organisms of each 


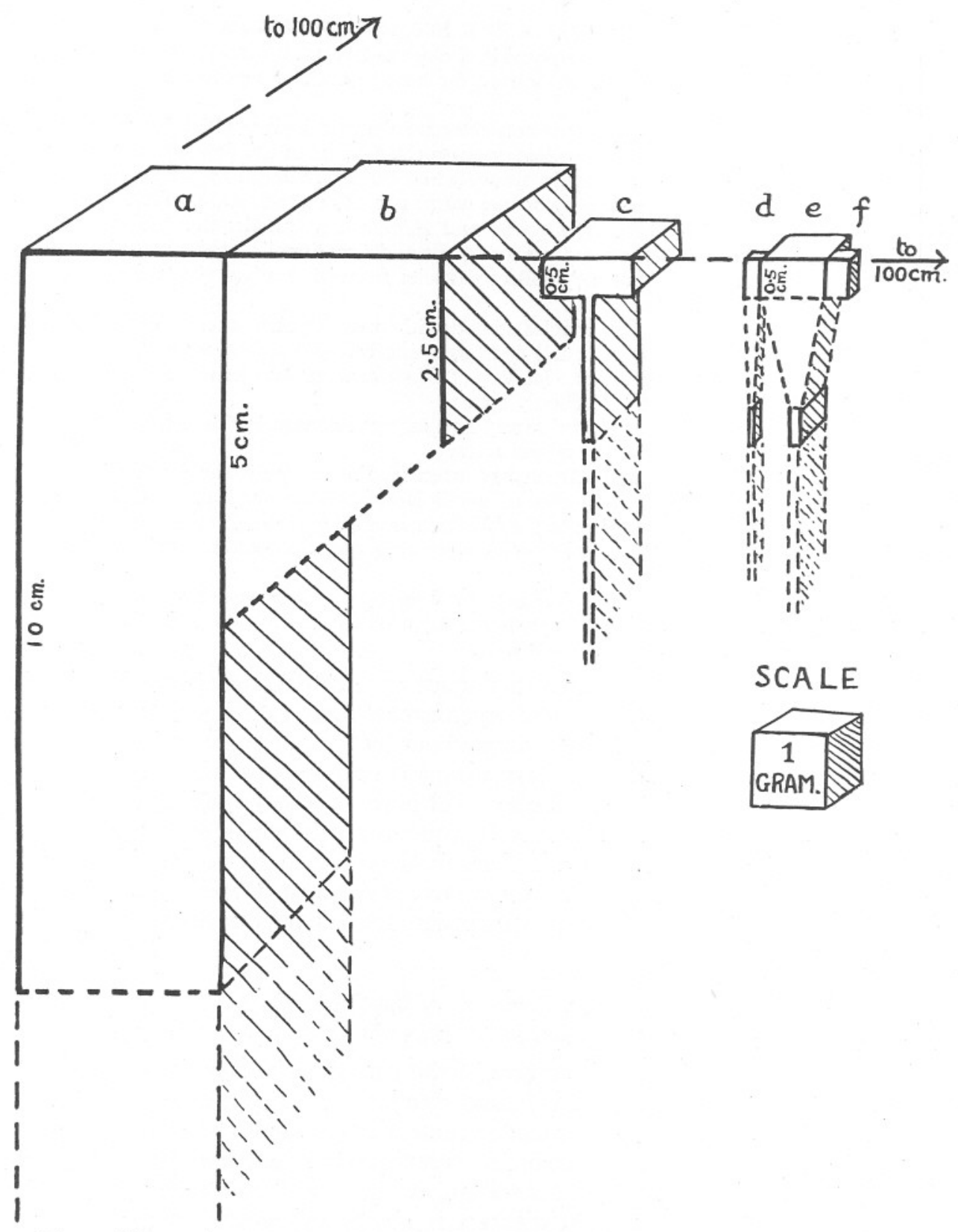

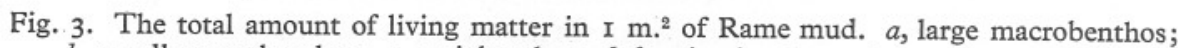
$b$, small macrobenthos; $c$, meiobenthos; $d-f$, microbenthos: $d$, protozoa; $e$, bacteria; $f$, bottom diatoms. For full explanation see text and Table VIII and for numerical data see Table IX. 


\section{TABLE VIII}

\begin{tabular}{|c|c|c|c|}
\hline Group & $\begin{array}{l}\text { Method of collection } \\
\text { and analysis }\end{array}$ & $\begin{array}{l}\text { Range of indi- } \\
\text { vidual weight }\end{array}$ & $\begin{array}{l}\text { Date of } \\
\text { collection }\end{array}$ \\
\hline Macrobenthos $(a)$ & Peterson grab, average depth of & Over 100 mg. & I2. vii. 39 \\
\hline $\begin{array}{l}\text { Macrobenthos }(b) \\
\text { Meiobenthos }(c)\end{array}$ & $\begin{array}{l}\text { sample Io } \mathrm{cm} \text {. } \\
\text { Same sample, sieve } \mathrm{I} \times \mathrm{I} \mathrm{mm} \text {. } \\
\text { Core sampler, sieve } 0 . \mathrm{I} \times 0 . \mathrm{Imm} \text {. }\end{array}$ & $\begin{array}{l}\text { (up to } 6 \mathrm{~g} \text {.) } \\
\text { I00-1 mg. } \\
\text { 0.05-0.0001 mg. } \\
\text { usually to } 0.001 \mathrm{mg} \text {. }\end{array}$ & $\begin{array}{l}\text { 12. vii. } 39 \\
\begin{cases}\text { I6. iii. } 39 \\
\text { I. v. } 39\end{cases} \end{array}$ \\
\hline Microbenthos $(d-f)$ & Core sampler, culture & $\begin{array}{l}\mathrm{I} \times \mathrm{IO}^{-4} \text { to } \\
\mathrm{I} \times \mathrm{IO}^{-9} \mathrm{mg} .\end{array}$ & 27 iv. 39 \\
\hline
\end{tabular}

\section{TABLE IX}

Weight per No. of individuals m. ${ }^{2}$ in g. per $\mathrm{m}^{2}$

LARge Macrobenthos $(a)$ :

75

56

Cucumaria elongata, dominant by wt.

Some burrowing crustacea missed below ro $\mathrm{cm}$.

SMaLl Macrobenthos $(b)$ : ...

Small polychaetes dominant, probably restricted to top layer, surface to $2.5-5 \mathrm{~cm}$.

Some small polychaetes missed

MeIobenthos (c):

Numbers minimal; weights of some groups uncertain; total weight a very rough approximation.

Variety of species - in surface $\frac{1}{2} \mathrm{~cm}$.

Nematodes and a few polychaetes, $0.5-2.5 \mathrm{~cm}$. .........

Nematodes probably extending deeper

Foraminifera, a few living ones confined to surface $\frac{1}{2} \mathrm{~cm}$.

\section{MICROBENTHOS:}

Large ciliates: some probably occurred, too scarce to be counted in culture

Protozoa $(d)$ :

Minimal numbers, trophic and resting forms:

In surface $\frac{1}{2} \mathrm{~cm}$.

At $2.5-3.0 \mathrm{~cm}$.

BACTERIA (e):

Plate count $\times$ roo; a very rough approximation to total live count: In surface $\frac{1}{2} \mathrm{~cm}$.

$$
\text { At } 2.5-3.0 \mathrm{~cm} \text {. }
$$

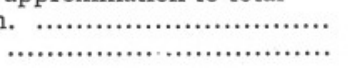

0.36

0.07

$355,000,000,000$ $72,000,000,000$

Воттом Diatoms $(f)$ :

Minimal numbers; only those on surface and probably capable of photosynthesizing are shown in diagram:

In surface $\frac{1}{2} \mathrm{~cm}$.

At $2 \cdot 5-3.0 \mathrm{~cm}$.

0.05

0.01

$590,000,000$

283,000,000

I $5,000,000$

I $40,000,000$

PlankTONIC DiATOMS, obtained by the culture method, represent an unknown fraction of the total diatoms deposited, either as resting spores or in a more or less moribund condition. The culture method showed I.64 g. per m. ${ }^{2}$ to be present in the surface layer on 27 April and $0.04 \mathrm{~g}$. in the layer at $2.5-3.0 \mathrm{~cm}$.; the highest figures obtained were about $25 \mathrm{~g}$. of living planktonic diatoms per square metre down to a depth of $\frac{1}{2} \mathrm{~cm}$. The planktonic diatoms, with the less recognizable detritus are best regarded as the organic matter deposited on to the habitat from an external source, and not being indigenous members of the benthos they have not been included in the diagram. 
group. These omissions are indicated in the diagram. Ideal sampling would give the numbers and weights of animals per unit area, e.g. per square metre, of deposit to the maximum depth of occurrence of the fauna, all samples being collected on the same date. The vertical distribution is indicated on the vertical faces of the rectangular blocks, the presentation being somewhat influenced by the methods of sampling. The square horizontal areas are adjusted to give volumes representing the total live weights of organisms in the different groups. The density is conventionally taken as I, i.e. I c.c., is equivalent to I g. The blocks are represented in perspective, the depth and width of the front face being absolute measurements; the blocks are placed in one corner of the whole square metre. Epifauna is excluded. Data concerning the method of collection and subdivision into size groups are given in Table VIII and the actual figures from which Fig. 3 is built up are given in Table IX.

\section{The Proportion of Organic Matter which consists of living Organisms}

The total organic matter is about I $\%$, i.e. Io mg. per g. dry weight of the deposit at Rame. It is obvious that the largest animals would not be included when making chemical determinations, and the chance of encountering them is very small. The micro- and meiobenthos and possibly some of the small macrobenthos would, however, be included in such determinations. The present state of our knowledge of the components of the organic carbon in a deposit is summarized below. 'Maximal' values (see p. 534) for the microbenthos and diatoms are used. Table $\mathrm{X}$ gives an indication of the composition of the organic matter ingested by a non-selective deposit feeder:

\section{TABLE X}

In the surface $\frac{1}{2} \mathrm{~cm} . \quad \begin{aligned} & \text { True microbenthos } \\ & \text { Planktonic diatoms }\end{aligned}$
Deeper in the deposit
$\begin{aligned} & \text { True microbenthos } \\ & \text { Planktonic diatoms }\end{aligned}$
In the top $2.5 \mathrm{~cm}$. Meiobenthos
Fraction biologically available to bacteria (see
Waksman \& Hotchkiss, I938; and Anderson, 1939)
Resistant fraction, mostly finally buried

Proportion of the total organic matter $0.3-0.03 \%$ At least $2 \cdot 5-0 \cdot 015 \%$ I/5th to I/IOth of the above A smaller proportion At least $0.02 \%$

$$
\begin{aligned}
& \text { Io-17 } \% \\
& \text { The rest }
\end{aligned}
$$

There is of course far more dead organic matter in the deposit than total organisms. The total indigenous fauna and flora amount to about 5-Io g. of organic carbon per square metre down to a depth of $10 \mathrm{~cm}$., while the detritus amounts to about I $\mathrm{kg}$. of organic carbon per square metre down to a similar depth. Of this, as seen in Table X, only a very small proportion consists of recently deposited or readily available food.

\section{Discussion}

In assessing the relative importance of the different groups in the turn-over of organic matter, the determination of the numbers and weights of organisms of all sizes is only the first preliminary. The relative rates of respiration must 
be taken into account. Krogh \& Spärck (1936) suggested that the small animals, such as copepods and nematodes, use three or four times as much oxygen per gram of living tissue per hour as do members of the macrofauna, and it is well known that bacteria and protozoa have a much higher rate of respiration than metazoa (see Krogh, I916; Heilbrunn, 1937, pp. 197-20I; and Cook \& Haldane, I93I). The smaller organisms therefore utilize relatively much more of the food supplies in the habitat than would appear from a direct comparison of quantities such as is made in Fig. 3.

It is impossible at present to do more than point out this important aspect of the subject because of the scarcity of data on the respiratory rates of the organisms concerned, and the complete lack of determinations under conditions of oxygen concentration, population density, food supply and temperature comparable to those found in the mud habitat. Some of the macrofauna may have an important mechanical effect on oxidation of organic matter in the deposit. For example, non-selective deposit feeders such as Scalibregma inflata, and forms such as tubicolous polychaetes and Calianassa subterranea which maintain currents of water in their tubes or burrows, may facilitate direct chemical oxidation or prolong the activities of aerobic bacteria.

The problem of the role of living micro-organisms in the food of detritus eaters is not yet capable of solution, because neither the food requirements nor the rate of feeding of any member of the Rame benthos have yet been worked out. It is to be expected that the quantitative food requirements and utilization will vary greatly between different species and with different modes of feeding. In so far as it throws any light on the subject, work (in progress) on Arenicola marina, a non-selective deposit feeder from the littoral zone, may be mentioned. From a study of this animal it seems that only a very small amount of food is required for maintenance (estimated from its respiratory rate), but that the quantity of micro-organisms ingested in a sand deposit is insufficient to meet this requirement. Account must be taken of the quantity of living food in a mouthful of ingested deposit, of the rate of feeding, of the population density of detritus eaters and hence of the interval which elapses before the same mud is again ingested. On the Rame ground it seems probable that, at the time of heavy deposition of planktonic diatoms, the quantity of diatoms present in the surface layers would be adequate for an animal feeding non-selectively and having a rate of feeding and food requirements of the same order as those of Arenicola. The quantity of true microbenthos and of planktonic diatoms found at other times of the year is such as to suggest that a non-selective deposit feeder would be largely dependent on dead detritic matter to form the bulk of its food supply. Selective deposit feeders and suspension feeders have access to a richer food supply in the extreme surface layer.

Although quantitatively inadequate to be of appreciable calorific value the microbenthos or the freshly deposited phytoplankton may be essential components in the food of the macrofauna in that they contain vitamins in all probability absent from detritus. This suggestion was first made by Hunt 
(1925), but in the light of more recent work on vitamins (see also Fox, I937) it requires modification in detail.

The food value of a population depends on the quantity present at any one time and the rate at which depletions are made good, i.e. the rate at which mud, in the form of faecal pellets, becomes part of the general habitat again and is reinvaded by such types of micro-organisms as are destroyed by passage through the gut of a metazoan. The rate of reproduction of the micro-organisms must also be sufficient for the invasion of newly deposited silt and detritus, if the community is to remain balanced. For bacteria and protozoa the food concentration, both local and general, plays so important a part in determining the rate of reproduction that it would be very difficult to find the normal rate in the habitat. From laboratory observations and literature (see Cutler \& Crump, 1924; Baier, 1935; and Mare, unpublished thesis) it can be tentatively suggested that the generation time for bacteria is about I- $3 \mathrm{hr}$., for small flagellates about Io hr. or less, for small ciliates Io-20 hr., and for bottom diatoms possibly about 2-3 days, under the conditions of light, temperature and food concentration in the Rame habitat. These rates, coupled with the quantities listed in Tables I-IV, make it probable that the reproductive rate would not be a limiting factor in the population density of the microbenthos providing that there were ample organic matter available. ZoBell \& Feltham (1938) estimated that 'several milligrams of bacterial substance are synthesized per day in the top $5 \mathrm{~cm}$. of I sq. metre of marine muds and although the majority is consumed by bottom animals the diet is perhaps supplemented by other types of food'. ${ }^{1}$ It was shown in Table VI that $75 \%$ of the Rame macrofauna was dependent on detritus and micro-organisms in and immediately above the habitat. The meiobenthos consists of both potential food supply and consumers. In comparing the annual potential food supply with the quantity of consumers, allowance must be made for the number of generations per annum of consumers, their food requirements for energy production and the extent to which the young stages draw on the food supply but fail to reach maturity. These factors are at present completely unknown.

The food relationships within the benthic community cannot be fully elucidated without reference to the relationship between the benthos and the water above the habitat, see Fig. I. This subject requires an immense amount of knowledge accumulated from the work of many investigators, and the work already done could only be dealt with adequately in a separate review. Studies on these lines are much less advanced in the sea than in freshwater lakes, where the greater accumulation of data and the circumscribed water mass make it possible to estimate the total productivity of the water and the part

1 The same authors (1942) investigated a very abundant bacterial flora, important in various ways, in a Californian tidal mud flat. Taking to million as the average number of living bacteria per c.c. of mud, they estimated that about I I g. dry wt. of bacterial substance would be synthesized per day per cubic foot of mud, thus forming an important source of food in the habitat. It should be noted that bacteria are far more numerous in that intertidal habitat than in the sublittoral Rame ground and that probably the fauna is also more abundant. 
utilized by the bottom fauna (see Rawson, I930; Juday, I940; and Deevey, I94I).

An outline of the balance-sheet of events on the sea bottom is given here, so that the small additions made in the present work may be seen in their correct places in the whole cycle. For an understanding of the annual cycle on the sea bottom, quantitative knowledge on the following subjects is required:

The annual deposition from the water, of plant, animal and faecal material.

The amount of photosynthetic production (if any) in the habitat itself (see p. 535).

The conversion of part of the detritus into protoplasm of micro-organisms and the mineralization of part. The numbers and quantities (see pp. 530-533) and the reproductive and respiratory rates when fully known would enable the annual production of living matter and the amount of turn-over of organic matter for which these organisms are responsible to be assessed.

The consumption of some of the living organisms and of detritus in oxidative metabolism by detritus eaters of all sizes. The numbers and weights (see pp 539-545) and the annual food requirements for energy production need to be known.

The accumulation of organic matter in the growth of the larger fauna, including the rate and efficiency of growth.

The utilization of detritus eaters by the carnivorous members of the community, as material for oxidation and growth.

The liberation of reproductive products to the water and the return of larvae to the habitat.

The removal of food from the habitat and of members of the community by scavengers and by predators from outside the habitat, e.g. by bottom-feeding fish. If the community remains approximately constant in total weight, the quantity removed is equal to the sum of the annual growth increments of such members of the fauna as are of a nature and size to serve as suitable food.

The return of nutrient salts and other important substances into the water as the result of bacterial activity and as excretory products of the fauna.

The loss from the food cycle of matter finally buried. This will consist of that resistant fraction which is biologically unavailable to bacteria of the upper layer and indigestible to the fauna. There may be some anaerobic decomposition of this material by bacteria deep in the deposit and perhaps slow autolysis; some marine humus may thus eventually be converted into petroleum.

\section{SUMMARY}

An attempt has been made to deal briefly but quantitatively with all size groups of the fauna and flora in a marine mud deposit.

It has been necessary to propose the following new terminology: the Macrobenthos, which is here equivalent to the macrofauna, the Meiobenthos, under which term are included copepods, nematodes, foraminifera, etc., and the Microbenthos, comprising the rest of the protozoa, bacteria, bottom diatoms and other algae; planktonic diatoms and coloured flagellates also occur on the bottom in the region investigated but are not regarded as true microbenthos.

A quantitative ecological study of the microbenthos has been started and the habitat is first described, stress being laid on points of importance to the microorganisms. 
The census method for bacteria was an agar-plate method and that for the protozoa and diatoms was a dilution culture method modified from that used by soil microbiologists.

These methods give minimal values for the total population and may safely be used for comparative purposes. The results are still tentative.

Typical figures for the minimal numbers and volumes of living protoplasm per gram of dry mud in the top $\frac{1}{2} \mathrm{~cm}$. layer are given in Tables I-IV.

The surface layer is much richer in all types of organisms than is the mud deeper in the cores. There is considerable local horizontal variation in numbers of bacteria and protozoa, suggesting dense aggregations.

Diatoms contribute by far the greatest bulk to the total volume of living micro-organisms; planktonic diatoms, particularly during the summer, completely outweigh the true microbenthos.

A seasonal variation has been shown in the numbers of bottom and planktonic diatoms. There was a fourfold increase in the quantity of bottom diatoms from winter to summer and while in the winter they were nearly as important as with the planktonic species (the ratio by volume being $\mathrm{I}: \mathrm{I} \cdot 7$ ), the planktonic species became overwhelmingly important in the summer (the ratio becoming $I: 67$ ).

The distribution of bottom diatoms and other photosynthetic organisms in the littoral and sublittoral zones has been briefly investigated.

At the Rame mud station there are many more organisms per gram of total deposit than there are in the Eddystone shell gravel. The proportion of living matter in the fine fraction of the gravel is, however, much higher and of the same order as at Rame.

Food relationships in the microbenthos are suggested and it is pointed out that the protozoa are sufficiently numerous for their interaction with the bacterial population to be highly important.

The total volume of the true microbenthos present at any one time is extremely small. Even in the surface layers at the Rame station its carbon content was only about $0.3-0.03 \%$ of the total organic carbon in the deposit. planktonic diatoms formed at least $2.5 \%$ of the total organic carbon in the spring and early summer.

The meio- and macrobenthos were briefly investigated, the numbers and weights per $\mathrm{m} .{ }^{2}$ being determined.

An interesting fauna of small polychaetes includes several new records for the Plymouth area.

The majority of the fauna ingest detritus either from the surface layer of the deposit or from the water immediately above the bottom.

The numbers and weights of most of the fauna and flora belonging to all size groups in the one habitat, as far as they were determined, are shown in Table IX and diagrammatically in Fig. 3. The relative amount of the living to the total organic matter present is given in Table X. These facts, when more adequately known and when combined with further qualitative observations on the food and feeding methods, will form a necessary basis for the discussion 
of food relationships throughout the community. Taking into account the amount of microbenthos represented in Fig. 3 and its respiratory and reproductive rates, the micro-organisms are probably capable of playing a not inconsiderable part in the turn-over of organic matter in the habitat when compared with the larger fauna.

The information so far accumulated is of a preliminary nature, and the numerical data presented must always be taken as indicating the magnitude of the quantities involved and not their exact values. Differences are so great, however, that it is possible to draw tentative conclusions. As it is no longer possible to obtain samples from the original habitat, these conclusions are put forward now, subject perhaps to modification in the future.

\section{REFERENCES}

ANDERSON, D. Q., I939. Distribution of organic matter in marine sediments and its availability to further decomposition. Fourn. Mar. Research, Vol. II, p. 225-35.

BAIER, C. R., I935. Studien zur Hydrobakteriologie stehender Binnengewässer. Archiv Hydrobiol., Bd. xxIx, pp. I83-264.

Blegvad, H., I9I4. Food and conditions of nourishment among the communities of invertebrate animals found on or in the sea bottom in Danish waters. Rep. Dan. Biol. Stat., Vol. xxII, pp. 4I-78.

BoRNEBUSCH, C. H., I930. The fauna of forest soils. Forstliche Versuchswesen in Dänemark, Bd. XI.

Boysen Jensen, P., IgI4. Studies concerning the organic matter of the sea bottom. Rep. Dan. Biol. Stat., Vol. xxiI, pp. I-39.

- I919. Valuation of the Limfjord I. Rep. Dan. Biol. Stat., Vol. xxvI, pp. I-44.

Cook, R. P. \& Haldane, J. B. S., I93I. The respiration of B. coli communis. Biochem. fourn., Vol. xxv, pp. 880-7.

CUTLER, D. W., I920. A method for estimating the numbers of active protozoa in the soil. Fourn. Agric. Sci., Vol. x, pp. 135-43.

CUTLER, D. W. \& CRUMP, L. M., I924. The rate of reproduction in artificial culture of Colpidium colpoda. Part III. Biochem. Fourn., Vol. xvirI, pp. 905-I2.

- 1929. Carbon dioxide production in sands and soils in the presence and absence of amoebae. Ann. Appl. Biol., Vol. xvI, pp. 472-82.

Cutler, D. W., CRUMP, L. M. \& SANDON, H., I922. A quantitative investigation of the bacterial and protozoan population of the soil with an account of the protozoan fauna. Phil. Trans. Roy. Soc., B, Vol. 21 I, pp. 317-50.

DeEvey, E. S. Jr., I94I. Limnological studies in Connecticut. VI. The quantity and composition of the bottom fauna of thirty-six Connecticut and New York Lakes. Ecol. Monogr., Vol. II, pp. 4I3-55.

ForD, E., I923. Animal communities of the level sea bottom in the waters adjacent to Plymouth. Fourn. Mar. Biol. Assoc., Vol. xIII, pp. I64-224.

Fox, D. L., I937. Carotenoids and other lipoid soluble pigments in the sea and deep marine muds. Proc. Nation. Acad. Sci. U.S.A., Vol. 23, pp. 295-301.

GARDINER, A. C., I937. Phosphate production by planktonic animals. Fourn. Cons. Int. Explor. Mer., Vol. xII, pp. I44-6.

Gause, G. F., I934. The Struggle for Existence.

Griessmann, K., I9I4. Über marine Flagellaten. Archiv f. Protistenk., Bd. 33, pp. I-78. 
GRoss, F., I937. Notes on the culture of some marine plankton organisms. Fourn. Mar. Biol. Assoc., Vol. xxI, pp. 753-68.

HarveY, H. W., I939. Substances controlling the growth of a diatom. Fourn. Mar. Biol. Assoc., Vol. xxiII, pp. 499-520.

- 1940. Nitrogen and phosphorus required for the growth of phytoplankton. fourn. Mar. Biol. Assoc., Vol. xxiv, pp. II5-24.

- I942. Production of life in the sea. Biol. Rev., Vol. I7, pp. 22 I-46.

Harvey, H. W., Cooper, L. H. N., Lebour, M. V. and Russell, F. S., I935. Plankton production and its control. Fourn. Mar. Biol. Assoc., Vol. xx, pp. 407-4I.

HeIlbrunn, L. V., 1937. An Outline of General Physiology.

Hunt, O. D., I925. The food of the bottom fauna of the Plymouth fishing grounds. Fourn. Mar. Biol. Assoc., Vol. xiII, pp. 560-99.

- 1926. A new method for quantitative sampling of the sea bottom. Fourn. Mar. Biol. Assoc., Vol. xIV, pp. 529-34.

Jenkin, P. M., I937. Oxygen production by the diatom Coscinodiscus excentricus Ehr. in relation to submarine illumination in the English Channel. Fourn. Mar. Biol. Assoc., Vol. xxII, pp. 30I-43.

JudAY, C., 1940. The annual energy budget of an inland lake. Ecology, Vol. 21, pp. $438-50$.

KaHL, A., I935. Die Tierwelt Deutschlands. Protozoa. I. Wimpertiere oder Ciliata (Infusoria), pp. I-886.

KROGH, A., I9I6. The Respiratory Exchange of Animals and Man. Monographs in Biochemistry.

KROGH, A. \& SPÄRCK, R., I936. On a new bottom sampler for investigation of the microfauna of the sea bottom-with remarks on the quantity and significance of the benthonic microfauna. K. danske vidensk. Selsk. Biol. Medd., Vol. xIII, 4, pp. 3-I2.

LACKEY, J. B., I936. Occurrence and distribution of the marine protozoan species in the Woods Hole area. Biol. Bull., Vol. Lxx, pp. 264-78.

Lebour, M. V., I922. The food of plankton organisms. Fourn. Mar. Biol. Assoc., Vol. xII, pp. 644-77.

- 1930. The Planktonic Diatoms of Northern Seas. Ray Society, London.

Lemmermann, E., I9I4. Die Süsswasser-flora Deutschlands, Österreichs und der Schweiz. Heft I. Flagellatae I. Pantostomatinae, Protomastiginae, Distomatinae.

Lloyd, B., I93I. Muds of the Clyde Sea area. II. Bacterial Content. Fourn. Mar. Biol. Assoc., Vol. xvII, pp. 75I-66.

LohmanN, H., I908. Untersuchungen zur Feststellung des vollständigen Gehalts des Meeres an Plankton. Wiss. Meeresuntersuch. Abt. Kiel, N.F., Bd. x, pp. I3I-370.

- - I9I I. Über das Nannoplankton und die Zentrifugierung kleinster Wasserproben zur Gewinnung desselben im lebendem Zustande. Int. Rev. Hydrobiol., Bd. Iv, pp. $\mathrm{I}-38$.

MacGinitie, G. E., I932. The rôle of bacteria as food for bottom animals. Science, Vol. 76, p. 490.

MARE, M. F., I940. Plankton production off Plymouth and the mouth of the English Channel in I939. Fourn. Mar. Biol. Assoc., Vol. xxiv, pp. 46I-82.

- The Significance of Micro-organisms and Organic Detritus in the Food Chains of a Marine Benthic Community. Unpublished thesis.

Marine Biological Association, 193I. Plymouth Marine Fauna (2nd edition).

MeIkLejohn, J., I930. The relation between the numbers of a soil bacterium and the ammonia produced by it in peptone solutions; with some reference to the effect on this process of the presence of amoebae. Ann. App. Biol., Vol. xvIr, pp. 6r4-37.

- 1932. The effect of Colpidium on ammonia production by soil bacteria. Ann. App. Biol., Vol. xIx, pp. 584-608. 
Moore, G. M., I939. A limnological investigation of the microscopic benthic fauna of Douglas Lake, Michigan. Ecol. Monogr., Vol. 9, pp. 537-82.

Moore, H. B., I93I. Muds of the Clyde Sea area. III. Chemical and physical conditions; Rate and nature of sedimentation; and Fauna. Fourn. Mar. Biol. Assoc., Vol. XviI, pp. 325-58.

MOore, H. B. \& NeILL, R. G., 1930. An instrument for sampling marine muds. Fourn. Mar. Biol. Assoc., Vol. xvi, pp. 589-94.

Orton, J. H., I9I4. On some Plymouth holothurians. Fourn. Mar. Biol. Assoc., Vol. X, pp. 2II-35.

PennaK, R. W., I940. Ecology of the microscopic metazoa inhabiting the sandy beaches of some Wisconsin Lakes. Ecol. Monogr., Vol. IO, pp. 537-6I5.

Petersen, C. G. J., I9I5. A preliminary result of the investigations on the valuation of the sea. Rep. Dan. Biol. Stat., Vol. xxiII, pp. 29-32.

- 1918. The sea bottom and its production of fish food. Rep. Dan. Biol. Stat., Vol. $\mathrm{xxv}, \mathrm{pp} . \mathrm{I}-62$.

Petersen, C. G. J. \& Boysen Jensen, P., igir. Valuation of the sea. I. Animal life on the sea-bottom, its food and quantity. Rep. Dan. Biol. Stat., Vol. xx, pp. $3-79$.

Picken, L. E. R., 1937. The structure of some protozoan communities. Fourn. Ecol., Vol. xxv, pp. 368-84.

Poole, H. H. \& Atkins, W. R. G., I929. Photo-electric measurements of submarine illumination throughout the year. Fourn. Mar. Biol. Assoc., Vol. XvI, pp. 297-324.

Rawson, D. S., I930. The bottom fauna of Lake Simcoe and its role in the ecology of the lake. Univ. Toronto Stud. Biol. Ser. xxxiv. Pub. Ontario Fish Res. Lab., Vol. 40, pp. I-I83.

REES, C. B., I940. A preliminary study of the ecology of a mud-flat. Fourn. Mar. Biol. Assoc., Vol. xxiv, pp. I85-99.

REMANE, A., I933. Verteilung und Organisation der benthonischen Mikrofauna der Kieler Bucht. Wiss. Meeresuntersuch., Abt. Kiel, N.F., Bd. xxI, pp. I6I-222.

Reuszer, H. W., I933. Marine bacteria and their rôle in the cycle of life in the sea. III. Distribution of bacteria in the ocean waters and muds about Cape Cod. Biol. Bull., Vol. 65, pp. 480-97.

Sandon, H., I932. The Food of Protozoa. Pub. Faculty of Science, Egyptian Univ., Cairo.

SINGH, B. N., I94I. Selectivity in bacterial food by soil amoebae in pure mixed culture and in sterilized soil. Ann. App. Biol., Vol. 28, pp. 52-64.

SMITH, J. E., I932. The shell gravel deposits and infauna of the Eddystone grounds. Fourn. Mar. Biol. Assoc., Vol. xvIII, pp. 243-78.

SPARROW, F. K., Jr., I937. The occurrence of saprophytic fungi in marine muds. Biol. Bull., Vol. 73, pp. 242-8.

Thamdrup, H: M., I935. Beiträge zur Ökologie der Wattenfauna auf experimenteller Grundlage. Medd. Komm. Havundersog. Kbh. Serie Fisk., Bd. x, pp. I-I25.

Trask, P. D., I932. The Origin and Environment of Source Sediments of Petroleum. Pub. Amer. Assoc. Petrol. Geol.

WAKSMAN, S. A., I933. On the distribution of organic matter in the sea bottom and the chemical nature and origin of marine humus. Soil Science, Vol. 36, pp. I2547.

WAKSMAN, S. A. \& CAREY, C. L., I935. Decomposition of organic matter in sea water. I, Bacterial multiplication in stored sea water. Fourn. Bact., Vol. 29, pp. 53I-43.

WaKsman, S. A. \& Hotchkiss, M., I937. Viability of bacteria in sea water. Fourn. Bact., Vol. 33, pp. 389-400.

_ _ 1938. On the oxidation of organic matter in marine sediments by bacteria. fourn. Mar. Research, Vol. I, pp. IOI-I8. 
Waksman, S. A., Reuszer, H. W., Carey, C. L., Hotchkiss, M. \& RenN, C. E., I933. Studies on the biology and chemistry of the Gulf of Maine. III. Bacteriological investigations of the sea water and marine bottoms. Biol. Bull., Vol. 64, pp. $183-205$.

ZoBeLL, C. E., I939. Occurrence and activity of bacteria in marine sediments. In Recent Marine Sediments. Pub. Amer. Assoc. Petrol. Geol.

ZoBell, C. E. \& ANDERSON, D. Q., 1936. Vertical distribution of bacteria in marine sediments. Bull. Amer. Assoc. Petrol. Geol., Vol. 20, pp. 258-69.

ZoBell, C. E. \& FelthaM, C. B., 1938. Bacteria as food for certain marine invertebrates. Fourn. Mar. Research, Vol. I, pp. 312-27.

- 1942. The bacterial flora of a marine mud flat as an ecological factor. Ecology, Vol. 23, pp. 69-78.

ZoBell, C. E. \& RittenberG, S. C., I938. The occurrence and characteristics of chitinoclastic bacteria in the sea. Fourn. Bact., Vol. xxxv, pp. 275-87. 